\title{
Recent Advances in Zinc Oxide Nanoparticles (ZnO NPs) for Cancer Diagnosis, Target Drug Delivery, and Treatment
}

\author{
Sumaira Anjum 1,*(D), Mariam Hashim ${ }^{1}$, Sara Asad Malik ${ }^{1}$, Maha Khan ${ }^{1}$, José M. Lorenzo ${ }^{2,3} \mathbb{D}$, \\ Bilal Haider Abbasi 4 (D) and Christophe Hano ${ }^{5}$ (D)
}

1 Department of Biotechnology, Kinnaird College for Women, Jail Road, Lahore 54000, Pakistan; mariamhashim07@gmail.com (M.H.); gabby_sara.malik@outlook.com (S.A.M.); maha.daud10@gmail.com (M.K.)

2 Centro Tecnológico de la Carne de Galicia, Avenida de Galicia 4, Parque Tecnológico de Galicia, 32900 San Cibrao das Viñas, Ourense, Spain; jmlorenzo@ceteca.net

3 Área de Tecnología de los Alimentos, Facultad de Ciencias de Ourense, Universidad de Vigo, 32004 Ourense, Spain

4 Department of Biotechnology, Quaid-i-Azam University, Islamabad 15320, Pakistan; bhabbasi@qau.edu.pk

5 Laboratoire de Biologie des Ligneux et des Grandes Cultures, INRAE USC1328, Eure \& Loir Campus, University of Orleans, 28000 Chartres, France; hano@univ-orleans.fr

* Correspondence: sumaira.anjum@kinnaird.edu.pk; Tel.: +92-30-0695-7038

check for updates

Citation: Anjum, S.; Hashim, M.; Malik, S.A.; Khan, M.; Lorenzo, J.M.; Abbasi, B.H.; Hano, C. Recent

Advances in Zinc Oxide

Nanoparticles (ZnO NPs) for Cancer Diagnosis, Target Drug Delivery, and Treatment. Cancers 2021, 13, 4570. https://doi.org/10.3390/

cancers 13184570

Academic Editor: Guilhem Bousquet

Received: 20 August 2021

Accepted: 10 September 2021

Published: 12 September 2021

Publisher's Note: MDPI stays neutral with regard to jurisdictional claims in published maps and institutional affiliations.

Copyright: (c) 2021 by the authors. Licensee MDPI, Basel, Switzerland. This article is an open access article distributed under the terms and conditions of the Creative Commons Attribution (CC BY) license (https:/ / creativecommons.org/licenses/by/ $4.0 /)$.
Simple Summary: Despite breakthroughs in medicine, cancer remains one of the most feared diseases. Traditionally, chemotherapies have been the treatment of choice. However, concerns about stability and poor solubility prevent them from being widely used. Destruction of healthy cells, hair loss, and drug resistance are all common side effects. In this aspect, nanotechnology opens up new avenues for cancer treatment. ZnO NPs are one of the most valuable metal oxide nanoparticles in cancer treatment owing to their high biocompatibility and low toxicity. The ability of ZnO NPs to selectively trigger the formation of reactive oxygen species and induce apoptosis has been critically appraised in this review. They are also the best contenders for diagnosis and tailored drug delivery in cancer therapeutics. Here, we extensively summarize the role of ZnO NPs in cancer diagnosis, target drug delivery, and treatment, which will help in future research advancements in the field of cancer theranostic.

Abstract: Cancer is regarded as one of the most deadly and mirthless diseases and it develops due to the uncontrolled proliferation of cells. To date, varieties of traditional medications and chemotherapies have been utilized to fight tumors. However, their immense drawbacks, such as reduced bioavailability, insufficient supply, and significant adverse effects, make their use limited. Nanotechnology has evolved rapidly in recent years and offers a wide spectrum of applications in the healthcare sectors. Nanoscale materials offer strong potential for curing cancer as they pose low risk and fewer complications. Several metal oxide NPs are being developed to diagnose or treat malignancies, but zinc oxide nanoparticles ( $\mathrm{nnO}$ NPs) have remarkably demonstrated their potential in the diagnosis and treatment of various types of cancers due to their biocompatibility, biodegradability, and unique physico-chemical attributes. ZnO NPs showed cancer cell specific toxicity via generation of reactive oxygen species and destruction of mitochondrial membrane potential, which leads to the activation of caspase cascades followed by apoptosis of cancerous cells. $\mathrm{ZnO}$ NPs have also been used as an effective carrier for targeted and sustained delivery of various plant bioactive and chemotherapeutic anticancerous drugs into tumor cells. In this review, at first we have discussed the role of ZnO NPs in diagnosis and bio-imaging of cancer cells. Secondly, we have extensively reviewed the capability of ZnO NPs as carriers of anticancerous drugs for targeted drug delivery into tumor cells, with a special focus on surface functionalization, drugloading mechanism, and stimuli-responsive controlled release of drugs. Finally, we have critically discussed the anticancerous activity of ZnO NPs on different types of cancers along with their mode of actions. Furthermore, this review also highlights the limitations and future prospects of ZnO NPs in cancer theranostic. 
Keywords: zinc oxide nanoparticles; cancer; ROS; drug delivery; diagnosis; anticancerous activity

\section{Hallmarks of Cancer}

Cancer is a primary cause of death and a significant impediment to extending life expectancy, with 10 million fatalities in 2020, according to a WHO report. The number of newly diagnosed cancer cases is projected to increase to 29.5 million per year, and projected cancer-related deaths are expected to increase to 16.4 million per year by 2040 [1,2]. Despite novel medicinal techniques and technological advancements, cancer remains one of the most lethal diseases [3,4]. It is a disease characterized by uncontrolled growth of the cells [5]. Cancer cells normally exist in the body and function like regular cells. Cancer is triggered when uncontrolled cell division leads to excessive cell proliferation. Cancer cells have the ability to build up their own blood supply, break away from the original organ, migrate, and spread to other body organs [6]. Proliferation can be lethal if allowed to persist and spread, and it is mainly due to the ability of cancer cells to ignore signals, whereas normal cells only replicate when they encounter signals. It may also be due to the mutations in genes offering checkpoints for cell proliferation [7]. Genomic instability may also lead to cancer, in which increased alterations occur in the genome during the entire life cycle of dividing cells [8]. Another phenomenon through which cancer progresses is angiogenesis, leading to the development of new blood vessels for proper supply of nutrients and oxygen to metastatic cancer cells [9]. Cancer is not caused due to a single factor. In fact, numerous internal and external factors are involved in the initiation of cancer. Internal factors include mutations in genes, genetic disorders, and hormone imbalances, and external factors include exposure to radiation, malnutrition, infectious agents, tobacco use, etc. [10]. Around $90 \%$ of cancerrelated deaths are caused by tumor spread, which is referred to as metastasis [11]. A hereditary gene defect is responsible for only $5-10 \%$ of all cancers. Despite the fact that all tumors are caused by a combination of mutations [12,13], these mutations occur as a result of interactions with the environment and carcinogens [14,15]. The main hallmarks of cancer are shown in Figure 1.

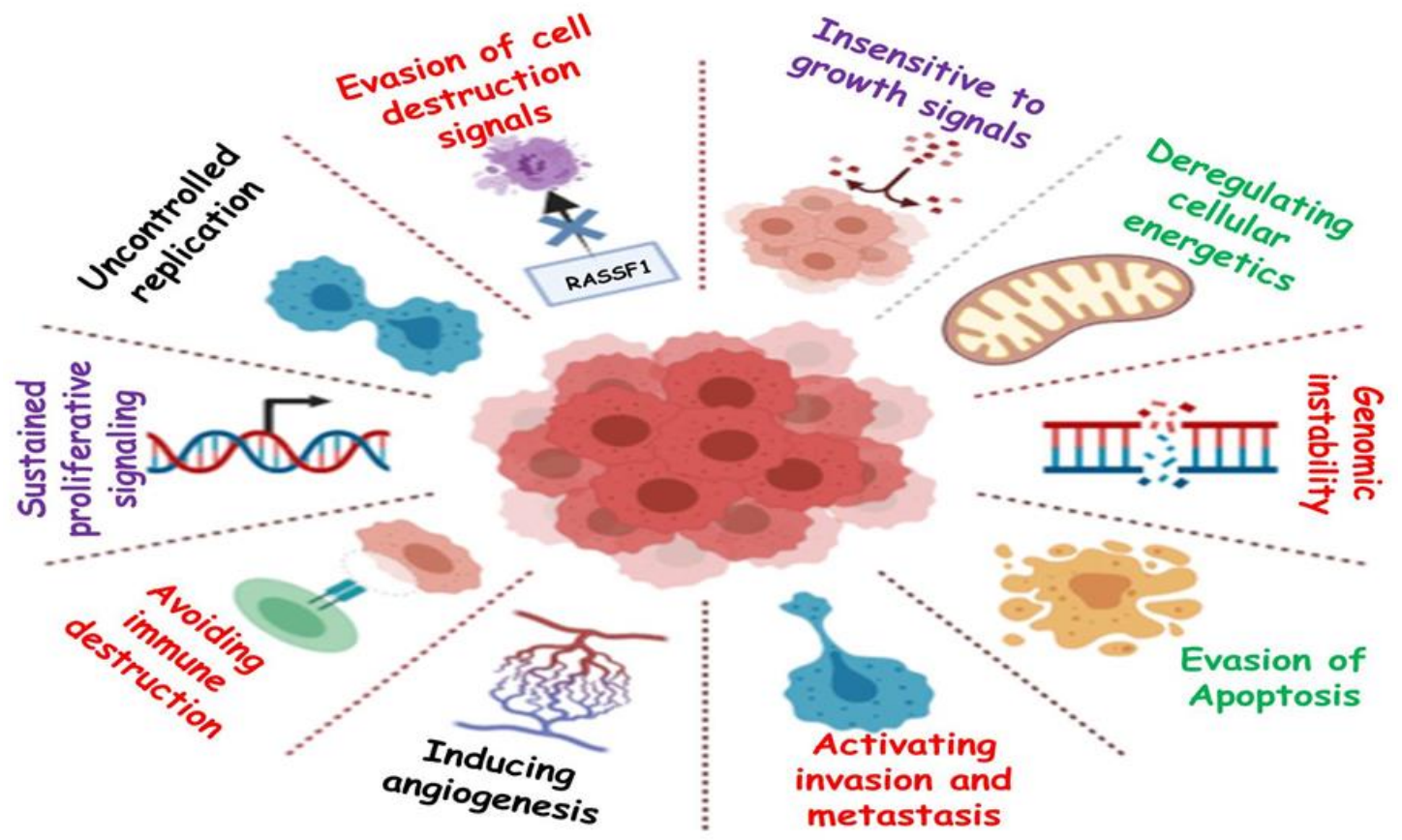

Figure 1. Graphical representation of the hallmarks of cancer. 


\section{Conventional Therapy vs. Nanotechnology-Based Therapy for Treatment of Cancer}

In conventional therapy, surgery, chemotherapy, radiotherapy, immunotherapy, phototherapy, and hormonal therapy are only a few of the therapeutic options for cancer as demonstrated in Figure 2C. Surgery could not be the final decision for all types of cancers and, chemotherapy in which medications are delivered intravenously into the body, has been the most often used treatment for cancer patients until now [16]. Despite advancements in chemotherapy, radiation therapy, immunotherapy, phototherapy and hormonal therapy, the main concern with these treatments is their negative side effects, which destroy healthy cells of the body along with damaged cells, which makes them a poor choice [17]. Conventional therapies are also constrained due to their low solubility, inability to invade tumors, nonspecific targeting, and inducing significant damage to the immune system and other organs, hence offering a low survival rate [18]. Conventional therapies are also known to develop resistance after exposure to subsequent doses, as represented in Figure 2A. However, in some circumstances, for example, when tumors are detected early, cures can be achieved, but recurrence and resistance are prevalent. Therefore, designing a drug delivery system that exclusively delivers deadly chemicals to tumors while leaving healthy cells alone is a difficult task [19].

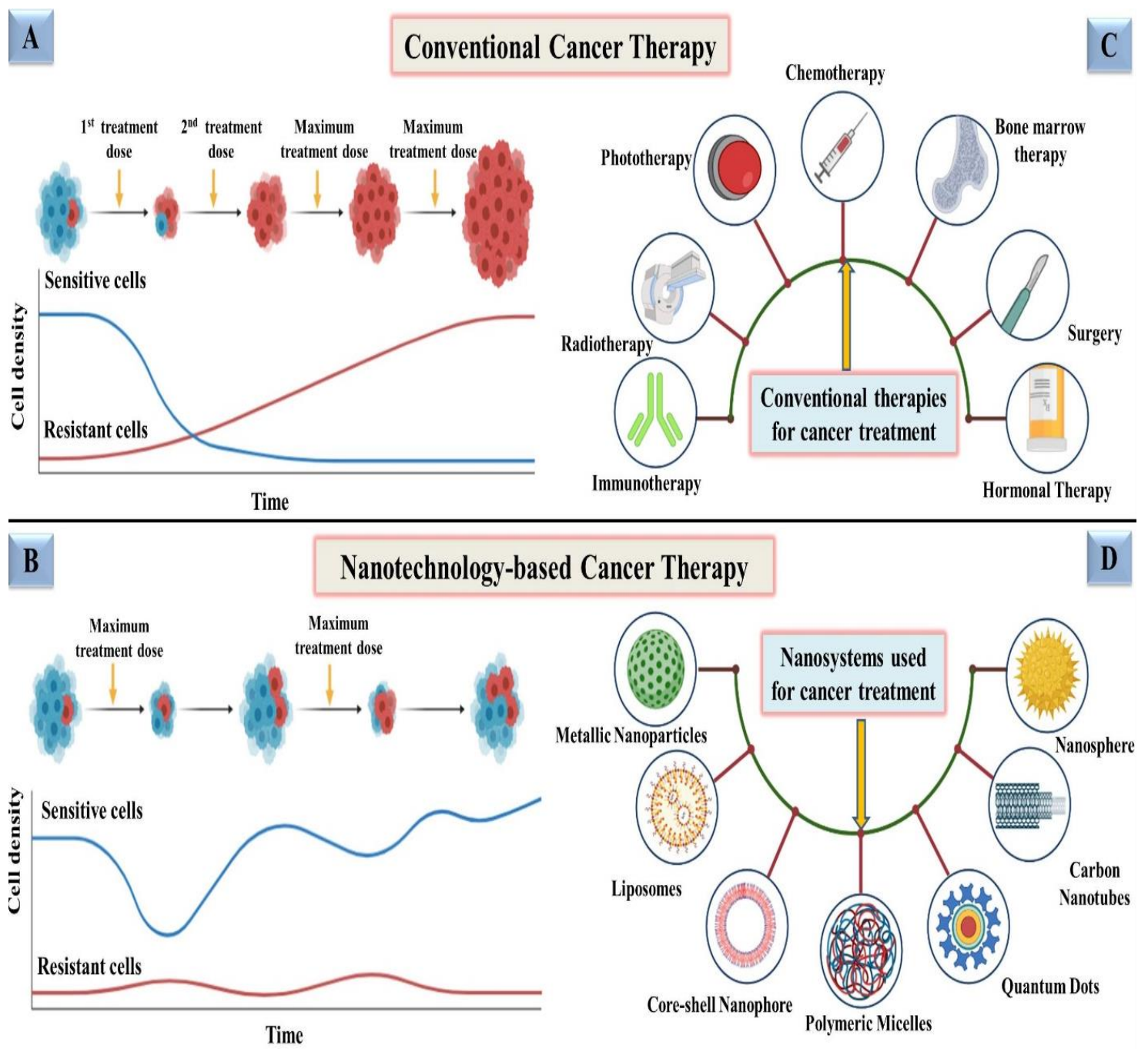

Figure 2. Schematic representation of a comparison between conventional vs. nanotechnology-based therapeutics for fighting cancer; (A) progression of resistance in cancer cells after exposure to subsequent doses of conventional therapies; (B) development of less resistance and more sensitivity in cancer cells after exposure to nanotechnology-based therapies even after maximum/higher doses; (C) representation of conventional therapies being employed for cancer treatment; (D) depiction of various nanotechnology-based nanosystems used for treating cancer. 
Nanoparticles (NPs) have attracted the attention of scientists in recent years because of their high efficacy and safety [20]. Therapeutic and diagnostic techniques based on nanotechnology have shown tremendous promise in improving cancer therapy in recent years [21,22]. Nanomedicine technologies have cleared the path for novel targeted cancer therapies by allowing therapeutic compounds to be encapsulated in nanoparticulate materials and delivered selectively to tumors via passive permeation and active internalization mechanisms. Employing NPs for therapeutic purposes has also been found to minimize resistance, addressing one of the most significant obstacles to conventional therapy as depicted in Figure 2B. Various studies are being conducted in order to identify more precise nanotechnology-based cancer treatments that have less adverse effects than conventional treatments [23]. Nanomedicine technology has progressed to the point that a number of nanomedicines for cancer treatment are already on the market, with many more in advanced phases of development and clinical testing employing various nanosystems, i.e., metallic nanoparticles, liposomes, quantum dots, carbon nanotubes, polymeric micelles, and nanospheres $[19,24-28]$ as shown in Figure 2D.

\section{Zinc Oxide Nanoparticles (ZnO NPs): Potential Candidate for Fighting Cancer}

Among all NPs, zinc oxide nanoparticles (ZnO NPs) are one of the most exploited candidates in drug delivery, cancer diagnosis, and treatment due to their unique physical and chemical properties. ZnO NPs are not only used in fighting cancer, but also proved to be very efficient in fighting many other diseases and in a variety of other sectors such as cosmetics, electronics, and the textile industry as well [29-32]. ZnO NPs can be synthesized chemically, physically, or biologically. Precipitation, microemulsion, chemical reduction, sol-gel, and hydrothermal procedures are some of the few examples of chemical methods that consume a lot of energy and also require maintenance of high pressure or temperature during the synthesis process [33-36]. ZnO NPs can be manufactured via physical processes such as vapor deposition, plasma, and ultrasonic irradiation, which are less common than chemical methods $[34,37,38]$. Nonetheless, these procedures typically necessitate a high level of energy and heavy equipment, which raises the price of the items. Another method for obtaining ZnO NPs is by biological synthesis, which has emerged as a more environmentally friendly technology [39]. Irrespective of the method employed, all types of $\mathrm{ZnO}$ NPs have proved to be efficient in combating cancers, in terms of their diagnosis, treatment, and sustained/targeted release of anticancerous drugs [40-42].

$\mathrm{ZnO}$ NPs are one of the most widely used metal oxide NPs in a variety of sectors and research institutions since they possess significant applications [43]. Because of the small particle size of nano-ZnO, the human body can easily absorb zinc. Since ZnO NPs are relatively affordable and less toxic than other metal oxide NPs, they offer a wide range of other medicinal uses, including antimicrobial, anti-diabetic, anti-inflammatory, anti-aging and also in wound healing and bio-imaging [44-47]. ZnO NPs have a high biocompatibility, allowing it to be used in a therapeutic environment for antibacterial, antifungal, antiviral, and anticancer properties [48]. Several types of inorganic metal oxides, such as $\mathrm{TiO}_{2}, \mathrm{CuO}$, and $\mathrm{ZnO}$ have been produced and have remained in current investigations, but $\mathrm{ZnO}$ NPs are the most interesting of these metal oxides since they are inexpensive to make, safe, and simple to prepare [49]. Furthermore, the following characteristics must be present in any agent intended for human consumption for treating various diseases. It should be nontoxic, must not react with food or the container, it should have a pleasant flavor or be tasteless, and it should not have an unpleasant odor. ZnO NPs are one such inorganic metal oxide that meets all of the aforementioned criteria, allowing them to be used safely as a medication, package preservative, and antibacterial agent [50,51]. Hence, the US Food and Drug Administration (FDA) has classified ZnO NPs as a "GRAS" (generally regarded as safe) substance [52]. ZnO NPs because, of their huge band gap (3.37 eV) and high exciton binding energy (60 meV), have a wide range of semiconducting capabilities, including strong catalytic activity, optics, UV filtering, anti-inflammatory, and wound healing [53]. They have also been widely used in cosmetics such as sunscreen lotions due 
to their UV filtering qualities [54]. ZnO NPs were first used in the rubber industry to provide wear resistance to rubber composites, improve the toughness and intensity of high polymers, and provide anti-aging properties $[55,56]$. ZnO NPs have also gained attention in biomedical imaging due to their ability to exhibit luminescence [57]. They have also attracted researchers towards the development of diagnostic tools, as they can also be employed in biosensing applications [58]. The unique attributes of ZnO NPs, due to which they can act as potent anticancerous agents, are listed in Figure 3.

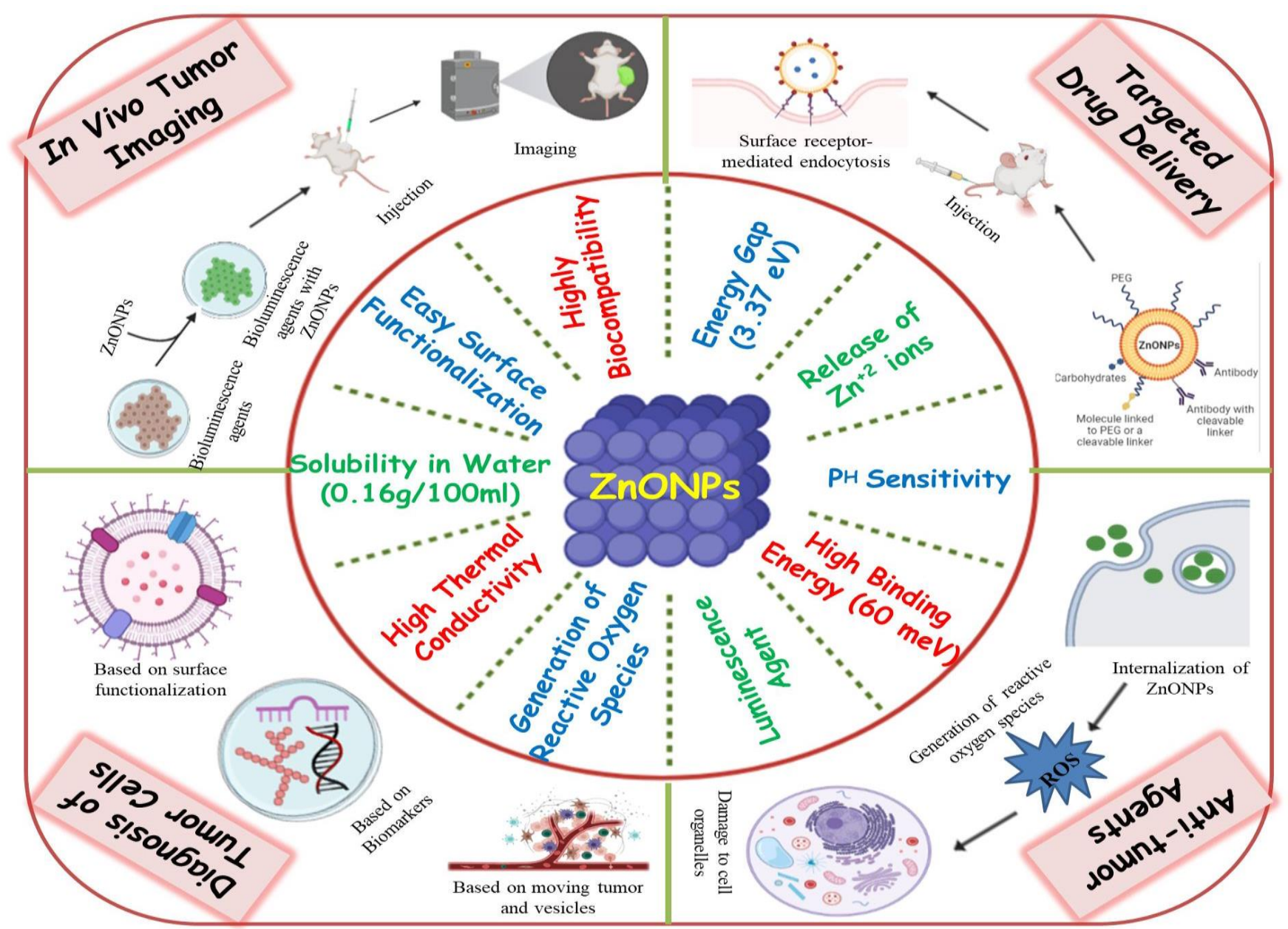

Figure 3. Graphical representation of the unique attributes of $\mathrm{ZnO}$ NPs and their various applications in fighting cancer.

$\mathrm{ZnO}$ NPs have also been studied as nanocarriers for a range of payloads, such as medicines, genes, proteins, and imaging agents [47,59]. Furthermore, ZnO NPs have also been exploited as a $\mathrm{pH}$-sensitive nanocarrier for tumor-targeted medication administration and intracellular drug release because they dissolve easily at low $\mathrm{pH}[60,61]$. Mounting evidence suggests that $\mathrm{ZnO}$ NPs are capable of destroying cancer cells by the production of reactive oxygen species (ROS), implying their potential as an anticancer agent [40,62]. Thus, these findings imply that $\mathrm{ZnO}$ NPs could be the best candidate for fighting cancer in terms of diagnosis, in vivo bio-imaging, sustained drug delivery, and as a multi-target anticancerous agent as illustrated in Figure 3.

\section{Role of ZnO NPs in Diagnosis of Cancer}

Despite advances in the development of novel therapy methods, cancer continues to be one of the main causes of death in humans. This is primarily due to the failure to detect malignancies at an early stage. Cancer may have progressed by the time it is discovered, making therapy difficult, if not impossible. To diagnose cancer at an early stage, it is vital to develop new diagnostic procedures or to improve the existing ones. To solve these 
bottlenecks, the recent progress in nanotechnology has made this possible. ZnO NPs are one of the best-suited nanomaterials to be used as sensitive tags for detecting various types of cancers due to their unique physiochemical features. Probes based on NPs paired with the relevant targeted molecules interact with biological systems and detect biological changes at the molecular level with remarkable precision [63].

Recent advances in unique properties of nanomaterials have heightened interest in their employment in biosensing sectors, resulting in substantial advancement in the fabrication of nanomaterial-based biosensors. The use of nanostructured materials to organize electrochemical sensing devices has a lot of appeal since they provide an electro-catalytic effect as well as a higher surface area, which is important for enzyme immobilization in electrochemical biosensors [64,65]. Early cancer detection, on the other hand, is crucial for patient survival and effective disease therapy, which demands delicate and specialized methods. Existing diagnostic methods (such as ELISA) are insufficiently sensitive, as they detect cancer biomarkers at later stages of the disease. Thus, approaches that are more realistic, quicker, and more affordable are needed over time [66,67]. Thus, the possibility of incorporating biosensors into point-of-care (POC) systems could be an attractive option. Biosensors for cancer detection have a wide range of applications.

Coupling electrochemical detection techniques with immunosensors and cyto-sensors allows for the development of quick, low-cost, and effective systems [67]. In a recent study, researchers have developed a screen-printed des-carboxy-prothrombin (DCP) immunosensor using ZnO NPs for accurate DCP assessment in the detection of liver cancer. DCP is a novel biomarker for detecting liver cancer that has a sensitivity of roughly $70 \%$ and a specificity of approximately 100\% [68]. As a result, the DCP immunosensor developed is simple, cheap, and reliable, with the potential to be used at home to screen for early-stage liver cancer using a point-of-care approach [69]. Similarly, an enhanced Interdigitated Electrode (IDE) based nanobiosensor for detecting viral oncogenes was developed by coating gold doped $\mathrm{ZnO}$ nanorods on the top of IDE chips surface with viral DNA receptors of human papillomavirus subtype-16 (HPV-16). Due to the higher sensitivity and biocompatibility of the created nanohybrid film, HPV-16-E6 oncogene biosensors demonstrate excellent detection of HPV-16-E6 oncogene (cancer biomarker for HPV infected cervical cancers). By detecting viral E6 gene targets as little as 1fM, this sensor displayed extraordinary sensitivity. The sensor also has a durability of over 5 weeks, excellent repeatability, and great HPV-16 discriminating abilities. As a result, the proposed sensor is a versatile instrument with a lot of potential for clinical diagnosis, especially in economically challenged nations and areas [70].

Among different forms of vitamin B, choline is a crucial component in the human body, as it plays an important role in several metabolic pathways. Deviation from normal choline levels result in sickness. In patients with triple-negative breast cancer (TNBC), choline and its related chemicals are reported to be increased at higher levels. Therefore, detection of choline in cancer cells using a nano-interfaced electrochemical biosensor is also of great interest to researchers nowadays. Recently, a working electrode composed of glassy carbon with a ZnO NPs interface was developed for electrochemical detection. Drop casting was used to immobilize the choline oxidase (ChOx) enzyme on a nano-interface. The linear range of the developed biosensor was $0.3 \mathrm{mM}$ to $5.1 \mathrm{mM}$, the detection limit (LOD) was $0.58 \mathrm{mM}$, and the quantification limit (LOQ) was $1.93 \mathrm{mM}$. The findings suggest that this biosensor could be utilized in clinical practice to identify breast cancer [71].

Nanopore layouts improve analytical performance by increasing the loading of active catalysts and allowing compounds to diffuse at faster rates [72]. Due to its cross-linked structure and ability to resist biodegradation, nanopore $\mathrm{ZnO}$ is considered to be the most stable [73]. Thus, manipulating the composition of materials during synthesis allows for the alterations in conductivity, distribution, shape, and size of $\mathrm{ZnO}$ nanofibers for their applications in developing biosensors. For the diagnosis of breast cancer, mesoporous $\mathrm{ZnO}$ nanofibers $(\mathrm{ZnOnF})$ were synthesized using an electrospinning technique with the diameter in a range of 50-150 $\mathrm{nm}$ and anti-epidermal growth factor receptor 
2 was used as a biomarker in conjugation. The outstanding impedimetric sensitivity of this immunosensor provides the fast detection (128 s) of cancer in a wide detection test range (1.0 fM-0.5 M). The suggested point-of-care cancer diagnostics have various advantages, including increased stability, quick monitoring, simplicity, cost effectiveness, and the capacity to identify other bio- and cancer markers [74].

$\mathrm{ZnO}$-nanosheets were prepared using zinc nitrate and triethanolamine at neutral $\mathrm{pH}$ and low temperature. K562 cells, a model of leukemia, were treated with ZnO-nanosheets for $20 \mathrm{~min}$ before imaging. After incubation, the cells emitted a yellow-orange light, indicating that $\mathrm{ZnO}$ nanostructures had successfully penetrated the cells [75]. Similarly, a stable $\mathrm{ZnO}$ polymer with core shell NPs using the sol-gel method was synthesized, which exhibited photoluminescence in solution and high quantum yield. It was evaluated on human hepatoma cells using $3 \mathrm{~nm} \mathrm{ZnO}-1$ (green fluorescence) and $\mathrm{ZnO}-2$ (yellow fluorescence), which did not show any toxicity against hepatoma cells. As these polymers are safe and cheap, they can be used in cell imaging as fluorescent probes in in vitro as well, implying potential uses in biological sectors [76].

\section{ZnO NPs in Sustained and Targeted Delivery of Anticancerous Drugs}

NPs are a good way to deliver site-specific drugs and bioactive agents in a controlled manner [77]. Drug formulation in biocompatible nanoforms is emphasized in pharmaceutical nanotechnology, which provides advantages in drug delivery. NPs improve drug efficiency and safety by improving bioavailability, providing targeted drug delivery, improving drug stability, and extending the drug's impact on the target tissue [78]. $\mathrm{ZnO}$ is used in current drug delivery systems due to its ease of manufacture, low cost, customizable structure, non-toxicity, high drug-loading capacity, programmable drug release ability, and targeted delivery [79-82]. Porous $\mathrm{ZnO}$ structures such as porous nanotubes, porous nanobelt, porous nanorods, and porous cages have been successfully used in targeted drug delivery systems $[83,84]$. In order for the drug to be delivered efficiently, surface functionalization of NPs can be done, which is achieved using various agents, i.e., ligands, linker chains, drugs, and markers. Through specific molecular interactions such as receptorligand-based interactions $[85,86]$, NPs accumulate in cells, which through endo/lysosomal escape on receiving an appropriate stimulus, release the drug, destroying its cognate target as depicted in Figure 4. Various types of internal and external stimulus are also involved in targeted delivery of anticancerous drugs. Thus, various $\mathrm{ZnO}$ nanostructures could be employed successfully in loading and targeted delivery of anticancerous drugs, as summarized in Table 1.

\subsection{ZnO NPs: Carrier of Anticancerous Bioactive Compounds in Sustained Drug Delivery}

Medicinal plants are a gift from nature to humanity, assisting them in their quest for improved health. Plants and their bioactive substances have been used in traditional medicine since the beginning of human history. Some medicinal plant species include phytochemicals that inhibit the progression and development of cancer by blocking cancer cell signaling pathways, activating DNA repair processes, and acting as antioxidants, demonstrating substantial anticancer action in terms of efficacy [87-89]. Among different plant bioactive compounds, taxifolin is considered a strong flavanol due to its unique structure with better antioxidant capabilities than other flavonoid compounds. In biomedical applications, however, its low bioavailability is a serious disadvantage. Biodegradable polymer coated $\mathrm{ZnO}$ NPs loaded with taxifolin were evaluated for their loading capacity and drug release behavior. The taxifolin-loaded $\mathrm{ZnO}$ NPs were found to be highly effective against the cancer cell line. Apoptotic signals were also observed to be induced by the produced particles in the selected cells. Even a lesser dose of $27 \mu \mathrm{g} / \mathrm{mL}$ was sufficient to inhibit MCF-7 cells. Further apoptotic experiments demonstrate that cell death is caused by fragmentation of the treated cells nuclear material. Thus, taxifolin-loaded ZnO NPs could be of prime importance in targeted drug delivery [90]. Similarly, functionalized nanohybrid hydrogels using L-histidine (HIS) conjugated chitosan with embedded $\mathrm{ZnO}$ 
NPs were developed for efficient delivery of polyphenol drugs such as naringenin (NRG), quercetin (QE), and curcumin (CUR). In the hybrid hydrogel, maximum loading efficiencies of $90.55 \%, 92.84 \%$, and $89.89 \%$ were optimized for NRG, QE, and CUR, respectively. The hydrogel was stabilized by HIS-chitosan conjugation, which exhibited long-term drug administration at $\mathrm{pH} 5$. When compared to free polyphenol drugs, the hybrid carrier showed a 15 to 30-fold increase in cytotoxicity in anticancer experiments on human skin carcinoma (A431) cells [91]. Likewise, ZnO NPs synthesized using the co-precipitation method were surface functionalized with PEG and beta cyclodextrin and loaded with a hydrophobic drug (curcumin). The brine shrimp assay indicated that functionalized $\mathrm{ZnO}$ NPs have improved cell imaging characteristics. It was discovered that the drug encapsulation efficiency was improved and the drug release was prolonged. The MTT assay revealed that they had a greater apoptotic effect on MCF-7 cells [92]. This sheds light on the intriguing potential of employing ZnO NPs as a promising agent in sustained release of bioactive anticancerous drugs.

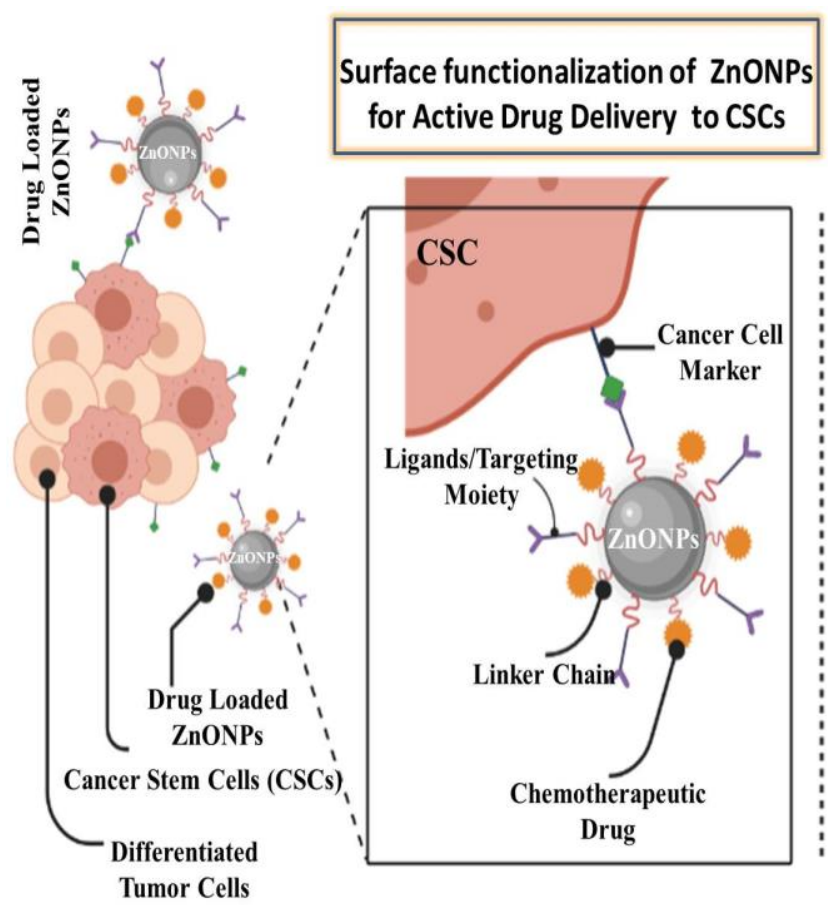

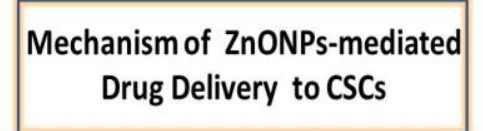

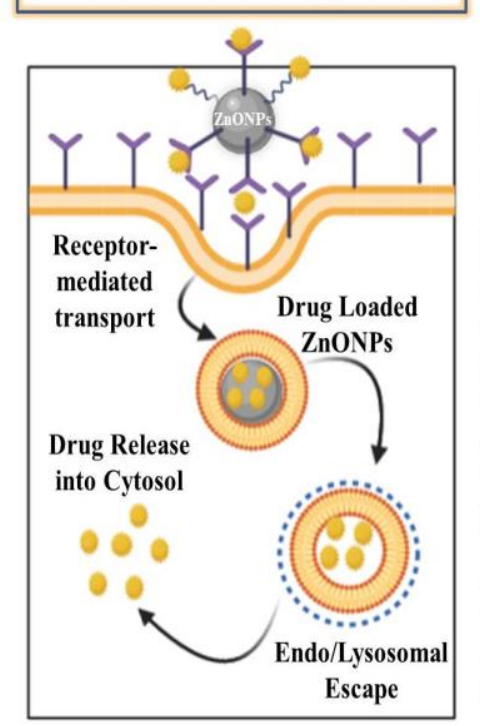

Stimuli Responsible for ZnONPsmediated Drug Release to CSCs

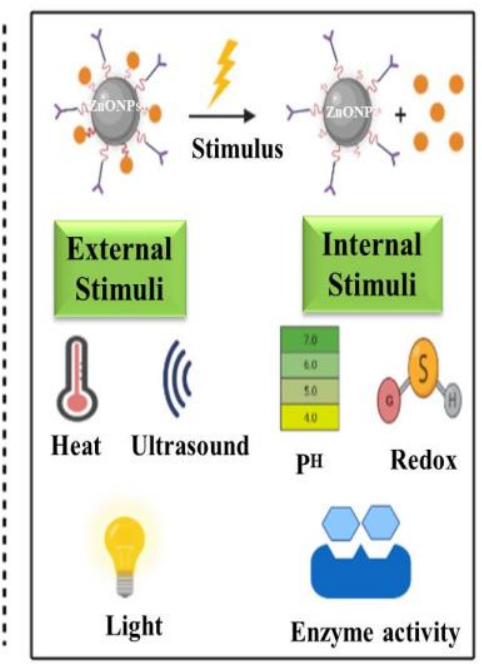

Figure 4. Graphical representation of the surface functionalization, mode of action, and various stimuli involved in targeted delivery of anticancerous drugs to cancer stem cells (CSCs) via ZnO NPs.

\subsection{ZnO NPs: Carrier of Conventional Chemotherapeutic Anticancerous Drugs in Sustained Drug Delivery}

The cytotoxic medications doxorubicin (DOX) and paclitaxel (PTX) are employed in traditional therapy, but they have severe side effects since the processes they demonstrate are commonly shared by cancerous and normal cells. As a result, cytotoxic medications kill both types of cells [93]. ZnO NPs are considered as one of the most efficient theranostic agents for cancer treatment. Furthermore, the semiconductor characteristics with a large band-gap assist in the generation of ROS [94]. Dox-loaded ZnO NPs were evaluated on MCF-7 cell lines and results showed higher cytotoxicity and drug released in a controlled manner [93]. For efficient drug delivery, folic acid-functionalized polyethylene glycol coated ZO nanosheet (FA-PEG-ZnO NS) was synthesized and evaluated on MDA-MB-231 cells. An anticancer drug, doxorubicin, was loaded on to FA-ZnO NS. DOX-loaded FA-ZnO NS carried heat and drug expressively to cancer cells along with its targeted synergistic effect of chemo-photothermal therapy. Enhanced uptake and cytotoxicity were observed against breast cancer cells. Thus, the DOX-FA-ZnO NS system facilitates controlled drug 
release and targeted chemo-photothermal therapy in a single system [95]. Another study shows the potential of DOX-loaded ZnO NPs in breast and colon carcinoma (HT-29) and results affirmed that DOX-ZnO NPs are efficient in drug delivery to MCF-7 cells and HT-29 cells with minimum toxicity and high therapeutic efficacy [84].

$\mathrm{ZnO}$ NPs were also used to increase the drug retention time in targeted drug delivery. In a recent study, for prolonged drug release, DOX was loaded into a water dispersed $\mathrm{ZnO}-\mathrm{QD}-$ chitosan-folate carrier. Encapsulation efficiency was discovered to be $75 \%$ as chitosan increases the stability of quantum dots (QDs) due to its hydrophilicity and cationic charge characteristics. The drug release response of the DOX-loaded ZnO-QD-chitosanfolate carrier was marked by a quick initial release followed by a regulated release. Results showed that the water dispersed ZnO QDs (2-4 nm) with long-term fluorescence stability could be exploited in the development of novel drug release carriers [96]. Likewise, for high transport of drugs, hollow nanocarriers are considered to be potential candidates since they provide substantial internal space in their core for drug loading [97,98]. Recently, a study was designed to establish a theranostic nanocarrier surface functionalized with folic acid for enhanced cellular uptake and unloading of paclitaxel drug in an acidic and malignant microenvironment. These $\mathrm{ZnO}$ nanocarriers showed a fluorescence reporting mechanism and drug release in a parallel manner. Thus, this "smart-targeting of chemotherapy" has the potential to improve the quality of life, recovery, and outcome of patients with breast cancer and possibly other organ tumors [99]. Moreover, the bacterial culture of Rhodococcus pyridinivorans NT2 was used to prepare anthraquinone ZnO NPs and cytotoxicity was checked against HT-29 cell lines. The MTT assay showed the ability of ZnO NPs to induce cytotoxicity in HT-29 cells in a dose-dependent manner. Thus, anthraquinone loaded $\mathrm{ZnO}$ NPs could be used as future candidates as anticancer drug delivery vehicles [100].

Ruthenium ( $\mathrm{Ru}$ ) has gained popularity as it exhibits an anticancer effect through its direct binding with DNA [101]. It tends to accumulate in neoplastic masses by using transferrin to invade tumors, leaving behind normal tissues and remaining in an inactive oxidation state, $\mathrm{Ru}$ (III) until it reaches the tumor site [102,103]. Surface-modified nanomaterials have the potential to deliver therapeutic compounds along with inhibition of cancer growth. Therefore, for efficient delivery of $\mathrm{Ru}$ pro-drug, $\mathrm{ZnO}-\mathrm{SiO}_{2}$ core shell NPs were coated with polyethylamine and surface functionalized with cholic acid. $\mathrm{ZnO}-\mathrm{SiO}_{2}$ NPs showed efficient Ru pro-drug delivery in cervical cancer treatment and tend to have a greater ability to successfully produce ROS in cancer cells. They were also found to be biocompatible and showed no acute toxicity. As a result, precise delivery of different therapeutic agents to their targeted areas was achieved, resulting in extremely efficient cancer therapy [104].

Likewise, microspheres have been created using hyaluronic acid (HA) as a gene delivery vehicle [105]. In cancer cells, the HA content rises [106], resulting in a less thick matrix, increased cell motility, and the capacity to invade healthy tissues. Because of its strong tumor selectivity and biocompatibility, HA could be employed to create tumortargeting drug delivery vehicles for anticancer drugs like PTX. Thus, the HA coated poly butyl cyanoacrylate (PBCA) ZnO NPs were made by initiating radical polymerization of butyl cyanoarylate (BCA) in the presence of HA with cerium ions. A model anticancer agent, PTX, was encapsulated in negatively charged NPs with a 90 percent encapsulation rate. In vitro release showed that HA alteration reduced the first burst release in the first $10 \mathrm{~h}$ and provided a continuous release over the next $188 \mathrm{~h}$. The hemolysis experiment and the MTT assay both showed that HA coating could greatly lower cytotoxicity. According to cellular uptake, HA-PBCA ZnO NPs were 9.5 times more effective than PBCA ZnO NPs in Sarcoma-180 (S-180) cells. As a result, HA-PBCA ZnO NPs may be an effective and safe vehicle for systemically administering hydrophobic anticancer drugs [107]. 


\subsection{ZnO Nanocomposite: Carrier of Various Conventional/Bioactive Anticancerous Drugs in Sustained Drug Delivery}

Nanocomposites have developed as viable options to overcome the limitations of various engineering materials. Nanocomposites are multiphasic materials having a diameter in the range of 10-100 $\mathrm{nm}$ in at least one phase [108]. Nanocomposites outperform standard microscale composites in terms of characteristics and may be synthesized using simple and low-cost processes. They can be prepared with enhanced physical, thermal, and other unique qualities [109]. Thus, they are widely employed to reduce the viability of cancers by enhanced drug delivery. As stated earlier, when bioactive compounds are conjugated to ZnO NPs, the results are superior to other NPs. To evaluate this, an MTT assay was carried out to investigate the anticancer properties of the synthesized $\mathrm{ZnO}$ conjugated L-asparaginase nanobiocomposite on the breast cancer cell line MCF-7. When MCF-7 cells were treated with $\mathrm{L}$-asparaginase conjugated $\mathrm{ZnO}$ nanobiocomposite, their viability was reduced to $35.02 \%$. This concludes the potential anticancerous activity of $\mathrm{ZnO}$ conjugated with L-asparaginase [110]. In another study, $\mathrm{ZnO}$ loaded quercetin nanocomposite were fabricated successfully by a cost-effective method. The synthesized $\mathrm{ZnO}$ nanocomposite was hexagonal in shape, having a diameter of $21-39 \mathrm{~nm}$, which was used as a carrier. It was observed that the $210 \mu \mathrm{g} / \mathrm{mg}$ of quercetin was loaded onto $\mathrm{ZnO}$ nanocomposite in acidic conditions, which are typically more favorable for cancer cells to proliferate. Results showed that the $\mathrm{ZnO}$ nanocomposite was found to release quercetin at a faster rate than the targeted MCF-7 cancer cells [111].

Green synthesized nanomaterials have proven to be more efficient in targeted drug delivery as compared to conventionally synthesized nanomaterials. In a recent study, $\mathrm{ZnO}$ nanocomposites were synthesized using water extracts from the seaweed Sargassum muticum and hyaluronan biopolymer (HA). In this study, cell lines such as pancreatic (PANC-1), colonic adenocarcinoma (COLO205), and ovarian (CaOV-3) along with acute promyelocytic leukemia (HL-60) were treated with the HA/ZnO nanocomposite. After $72 \mathrm{~h}$ of exposure to a $\mathrm{HA} / \mathrm{ZnO}$ nanocomposite, the MTT assay revealed that nanocomposites were most hazardous to HL-60 cells, inducing elevations in caspase 3/7 and inducing G2/M cell cycle arrest, while the normal human lung fibroblast (MRC-5) cell line remained unaffected. As a result of the findings, the $\mathrm{HA} / \mathrm{ZnO}$ nanocomposite developed through green synthesis has a great potential as a cancer therapeutic agent [112].

Curcumin is widely known due to its ability to destroy cancer cells, but its poor water solubility and low bioavailability pose significant hurdles to its medicinal usage. Therefore, a study was designed to build a curcumin loaded poly methyl methacrylate (PMMA) and poly ethylene glycol (PEG) ZnO bio-nanocomposite containing insoluble curcumin and poorly soluble $\mathrm{ZnO}$ NPs to improve the bioavailability and ultimately the efficacy of curcumin. PEG and PMMA are suitable for usage in controlled-release polymer systems due to their demonstrated safety. The created nanocomposite was able to transport a substantial amount of curcumin while rapidly releasing its therapeutic payload at low $\mathrm{pH}$, enhancing curcumin bioavailability and anticancer activity on gastric cancer (AGS) cells [79]. As a result, these bio-nanocomposites could be a potential anticancer medicine alternative in the near future. 
Table 1. Role of various ZnO NPs-formulations in targeted/sustained delivery of anticancerous drugs.

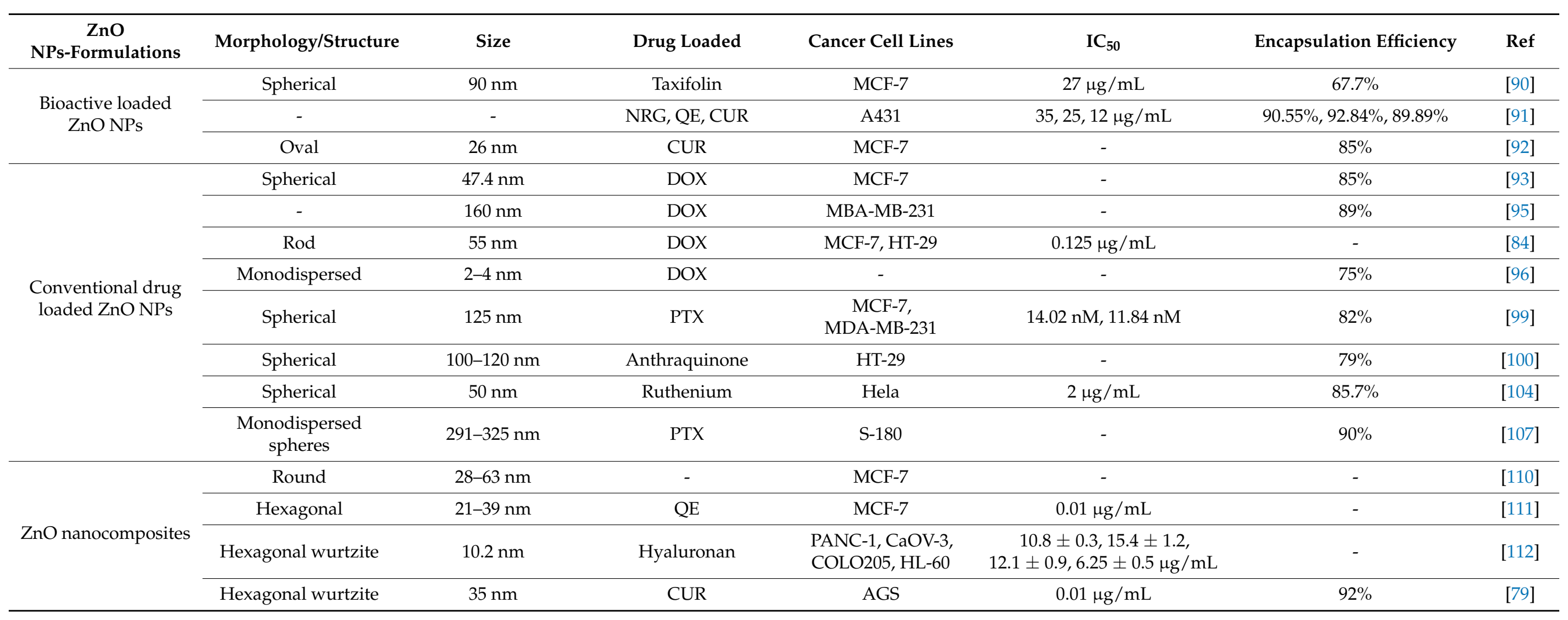




\section{In Vitro and In Vivo Anticancerous Activity of ZnO NPs}

Cancer is typically treated by conventional therapies such as chemotherapy, radiotherapy, and surgery. Although all these therapies seem to be very effective for killing cancer cells in theory, in fact, these nonselective therapies also introduce a lot of serious side effects $[113,114]$. Recently, nanotechnology-based nanosystems, with high biocompatibility, easily surface functionalization, cancer targeting, and drug delivery capacity, have demonstrated the potential to overcome these side effects. Among different nanomaterials, $\mathrm{ZnO}$ NPs are considered to be safe both in in vitro as well as in vivo. Owing to their highly biocompatible and biodegradable nature, $\mathrm{ZnO}$ NPs can be selected as potent nano-platforms for cancer treatment [115-117]. The use of ZnO NPs in cancer treatment has grabbed the interest of researchers and currently, a lot of studies have been published demonstrating the anticancerous activity of ZnO NPs [118-120]. Here, we have presented the anticancerous activity of $\mathrm{ZnO} N P s$ according to various types of cancers as summarized in Table 2.

\subsection{Liver Cancer}

Liver cancer is the only one of the top five most deadly malignancies that has an increase in occurrence annually [121]. Hepatitis B and C viruses, smoking, diabetes, obesity, and other dietary exposures are all risk factors associated with liver cancer. Liver cancer patients have a dismal prognosis [122]. Only 5\% to $15 \%$ of people are candidates for surgical removal, which is only recommended for cancer patients in their early stages [123]. Long-term usage of chemotherapeutic medications, such as sorafenib, raises additional concerns of toxicity and/or pharmaceutical inefficacy. As a result, neither existing ablation treatments nor chemotherapies have been demonstrated to improve the outcomes of this severe disease appreciably [124]. In order to analyze the anticancerous efficiency of ZnO NPs, human hepatocellular carcinoma (HepG2) and normal rat cells (hepatocytes) were employed, and cytotoxicity was determined using the MTT assay. It was shown that concentrations up to $5 \mu \mathrm{g} / \mathrm{mL}$ did not result in a significant loss in viability of cells. However, concentrations of $10-15 \mu \mathrm{g} / \mathrm{mL}$ proved beneficial. HepG2 viability was reduced by $33 \%$, whereas hepatocytes remained unaffected [40]. Similarly, at doses of $14-20 \mu \mathrm{g} / \mathrm{mL}$ for $12 \mathrm{~h}$ and $24 \mathrm{~h}, \mathrm{ZnO}$ NPs showed a reduction in cell viability and apoptosis was induced in HepG2 cells [125]. In conclusion, ZnO NPs mediate ROS through the p53 pathway, which selectively triggers apoptosis in cancer cells.

Apoptosis and cell cycle regulation are intimately linked. As a result, lack of apoptotic processes leads to unregulated cell proliferation, which results in growth of cancer tissues and abnormalities [126]. The protein p53 has been found to be triggered in response to DNA damage induced by oxidative stress [127]. p53 also induces cell apoptosis and the activation of other genes involved in cell cycle checkpoint activation $[128,129]$. The Bax protein (a member of the Bcl2 family) is activated in response to numerous genotoxic stressors and interacts with the Bcl2 protein [130]. p53 stimulates Bax transcription directly [131]. The induction of Bax by activated p53 can counteract the anti-apoptotic effects of the Bcl2 protein. As a result, cells with a Bax deficiency are resistant to apoptosis-inducing stimuli $[132,133]$. In order to analyze this, an experiment was conducted to evaluate the cytotoxic and anticancerous activity of ZnO NPs on rat liver and spleen. Gene expression profiling using apoptotic markers, i.e., p53, BAX, and Bcl-2, was also carried out in this study. The results confirmed the upregulation of p53 and BAX genes, which were responsible for inducing apoptosis in human hepatoma cell lines (HepG2 and HUH7) [134].

Caspases are a type of cysteine protease that is thought to be involved in the apoptotic process. In mammalian cells, caspase- 3 and caspase- 9 have been identified as significant mediators of apoptosis. Their actions are regarded as adequate indicators of cytotoxic response [135]. ZnO NPs were exposed to a liver cancer cell line (Huh 7) and findings indicated that nano- $\mathrm{ZnO}$ stimulated autophagy, upregulated the expression of caspase 3 and p53 markers, and triggered apoptosis in liver cancer cells, hence limiting liver cancer 
cell growth and proliferation [136]. The mechanism suggested that caspase activation contributed to $\mathrm{ZnO}$ NPs triggered apoptotic death.

There are numerous ways of synthesizing NPs of desired shapes and sizes, including physical and chemical processes, but their limitations limit their application. Biological nanoparticle synthesis, on the other hand, is a novel and economically viable strategy in the field of "green chemistry" [137-140]. It is simple, safer, greener, and easier to scale up; it is also energy and cost efficient, and it can be accomplished under normal circumstances without the use of toxic substances [137-139]. Thus, the potential of ZnO NPs synthesized from Eclipta prostrata was tested on HepG2 cells, which showed that $100 \mathrm{mg} / \mathrm{mL}$ induced significant cytotoxic effects, whereas activation of caspase 3 and DNA fragmentation assays confirmed the apoptotic features of the cells [41]. Similar results were reported using a leaf extract of Pandanus odorifer [118]. ZnO NPs were also assessed in conjugation with Geranium wallichianum leaf extracts. The MTT assay was used to evaluate the cytotoxicity of the produced $\mathrm{ZnO}$ NPs against HepG2 and the findings showed that HepG2 cells exposed for $48 \mathrm{~h}$ to various dosages of $\mathrm{ZnO}$ NPs significantly reduced the metabolic activity of HepG2 cancer cells. Increases in $\mathrm{ZnO}$ NPs concentrations resulted in a steady decrease in metabolic activity. At $1000 \mu \mathrm{g} / \mathrm{mL}$, the maximum inhibitory potential (71\% mortality) was attained, and cytotoxicity potency decreased as concentration was decreased. Thus, the reduction in metabolic activity caused by ZnO NPs might be due to the anticancerous potential of these NPs [42]. Green synthesis can also be achieved by employing microorganisms such as bacteria, fungi, and algae. Thus, cytotoxic as well as anti-angiogenic effects of ZnO NPs synthesized from an algae, Sargassum muticum, were evaluated on HepG2 cells and results affirmed that concentrations of $2800 \mu \mathrm{g} / \mathrm{mL}$ at $72 \mathrm{~h}$ of exposure left only $4.5 \%$ of cells alive, thereby affecting a survival rate of $95 \%$. This suggests that ZnO NPs synthesized from plant sources can be used as a supplemental drug in the treatment of cancer as it decreases angiogenesis and activates apoptosis [141].

\subsection{Lung Cancer}

Lung cancer continues to be the leading cause of cancer-related deaths in both men and women all over the world [142]. Cigarette smoking habits are strongly linked to lung cancer incidence and mortality. Lung cancer incidence and mortality are likely to rise in future decades as smoking rates peak, often first in males, then in women, before dropping following the implementation of comprehensive tobacco control initiatives [143-145]. In this regard, nanocomposites have proven favorable in several biomedical applications due to their unique electrical, mechanical, and optical properties [146-148]. In a study, a precipitation technique was employed to prepare a pectin-guar gum-zinc oxide (PECGG-ZnO) nanocomposite. This combination was employed as an immunomodulator to particularly attack cancer cells, which showed enhanced anticancerous effects by increasing concentrations from 25 to $200 \mu \mathrm{g} / \mathrm{mL}$ of the NPs. When compared to untreated human peripheral blood lymphocytes (PBL), pretreated PBL with nanocomposite showed increased cytotoxicity against lung cancer (A549) [149].

$\mathrm{ZnO}$ NPs have also attracted the attention of researchers due to their use for photothermal therapy (PTT) in treatment of cancer [95]. By generating heat and then irradiating it with near-infrared (NIR) light, cancer cells can be thermally abated. PTT may provide greater temporal-spatial selectivity and reduced invasiveness as compared to other established therapeutic approaches [150]. In a recent study, chemo-photothermal treatment of A549 cells was investigated utilizing a nano-sized composite of ZnO NPs and berberine (BER). A single hybrid nanocarrier containing BER and ZnO NPs could carry both entities to the tumor at the same time, resulting in boosting anticancer efficacies. Thus, BER-ZnO NPs were found to have improved anti-proliferative properties in A549 cells through increasing cytotoxicity. In vivo tests on rats revealed no evidence of renal or hepatotoxicity, respectively. As a result, BER-ZnO NPs could be safely used as an injectable formulation for chemo-photothermal therapy for lung cancer [151]. 
Plants have useful bioactive molecules such as alkaloids, phenols, flavonoids, saponins, and tannins that help them cope with stressful environments. NPs made from such promising plants are shown to have increased activity. As a result, A549 was tested using ZnO NPs synthesized from Mangifera indica. The influence of ZnO NPs on the viability of A549 cells was comparable to that of the standard medication used, cyclophosphamide. Increasing the concentration of NPs boosted their antioxidant activity and extremely stable ZnO NPs with substantial antioxidant and anticancer properties were found [152]. Likewise, $\mathrm{ZnO}$ NPs prepared from Raphanus sativus triggered cytotoxicity and showed significant results in the A549 cell line. Intense changes in morphology were observed after treatment, and the authors suggested that the high surface area to volume ratio of ZnO NPs may lead to enhanced cytotoxicity. Moreover, phyto-constituents present in the plant from which $\mathrm{ZnO}$ NPs was synthesized might also be responsible for the enhanced anticancer activity of these NPs [153]. Similarly, the A549 cancer cell line was treated with various dosages of $\mathrm{ZnO}$ NPs ranging from 1 to $100 \mu \mathrm{g} / \mathrm{mL}$ produced from Pandanus odorifer leaf extract. At dosages of 50 and $100 \mu \mathrm{g} / \mathrm{mL}$, viability was reduced by 60-70 percent [118]. Thus, the biogenic approach to synthesizing ZnO NPs could prove useful in minimizing the use of toxic chemicals and elevating therapeutic efficiency.

\subsection{Breast Cancer}

The lack of equilibrium between proliferation and apoptosis represents a major hurdle for damaged cells to be cleared out through apoptosis. Activating apoptotic pathways in tumor-affected cells is an important part of cancer treatment [154]. The tumor suppressor p53 gene and the caspase enzyme aid in the regular examination of cells and their prevention of malignancy [155]. Zinc has a critical part in the stimulation of the apoptosis-inducing caspase-8 enzyme, as well as regulating the effect of p53, a tumor suppressor gene [156]. Caspase-9 is also an essential target of zinc [157], as it is a potent inducer of caspase- 3 and other enzymes that cause nuclear membrane disintegration and cellular death. Hence, p53, Bax, and caspases are considered key apoptotic markers while targeting cancers. In order to evaluate this, MCF-7 was exposed to ZnO NPs, which showed inhibition of cancer cells in a dose-dependent manner. Apoptosis in MCF-7 was triggered since markers such as p53, Bax, JNK, and p21 were upregulated [119]. Similarly, activation of caspase 8 and the p53 pathway activated apoptosis in MCF-7 cells on exposure to $\mathrm{ZnO}$ NPs [158]. Likewise, biosynthesized ZnO NPs about the size of $40 \mathrm{~nm}$ and a spherical morphology induced apoptosis in a dose-dependent manner in the MCF-7 cell line [159]. Murine breast cancer cell lines, TUBO and MCF-7 were exposed to different doses of $\mathrm{ZnO}$ NPs and the expression of caspase 3 and caspase 8 genes was evaluated. At doses of 4 and $8 \mu \mathrm{g} / \mathrm{mL}$, overexpression of caspase 3 was detected, whereas significant overexpression of caspase 8 was only observed at the dose of $8 \mu \mathrm{g} / \mathrm{mL}$. These findings showed that ZnO NPs have the ability to induce apoptosis in both cancer cell types [160].

Recently, an extensive study on anti-tumor activity of ZnO NPs against various breast (MCF-7, MDA-MB-231) cancer cell lines was conducted. In this study, ZnO NPs (40 nm) induced cell selective toxicity and triggered apoptosis by enhancing BAX expression [161]. Likewise, two breast cancer cell lines, MCF-7 and T47D, were exposed to ZnO NPs, which showed dose-dependent inhibitory action and induced apoptosis. Results were confirmed via annexin $\mathrm{V} / \mathrm{PI}$ staining, which showed no toxic effects on normal human embryonic kidney (HEK293) cells [162]. Thus, ZnO NPs can be efficiently employed as natural apoptosis inducers in human breast cancer cells.

Synthesis of ZnO NPs using a biogenic approach is a straightforward, practical, and competitive method in comparison to other NPs and delivers a high yield with a unique physical appearance [163]. Along with this, ZnO NPs have solely sparked a lot of interest recently, due to their wurzite structure, hexagonal phase, and n-type semiconductor [164]. Thus, ZnO NPs synthesized from Gymnema Sylvestre showed toxicity by inducing ROS, MMP damage and apoptotic morphological alteration. Activation of caspase and Bax was also observed in MCF-7 cell lines [165]. Cytotoxicity studies also showed Pongamia 
pinnata coated $\mathrm{ZnO}$ NPs at dosages greater than $50 \mu \mathrm{g} / \mathrm{mL}$ severely reduced the viability of breast cancer MCF-7 cells in a single treatment and also effectively inhibited the biofilm formation of Candida albicans [166]. As confirmed by MTT assay [118], synthesizing ZnO NPs using leaf extract of Pandanus odorifer proved beneficial in decreasing the viability of MCF-7 cell line. The MCF-7 cell line was also utilized to investigate anti-breast cancer cytotoxicity, and the findings demonstrate that ZnO NPs generated from root extract of Withania somnifera had significant cytotoxicity in a dose-dependent fashion [167]. ZnO NPs biosynthesized from Knoxia sumatrensis inhibited anti-proliferative activity on MCF-7 cell line [168]. In another study, $\mathrm{ZnO}$ nanorods were prepared using Santalum album and dose-dependent cytotoxicity was found against MCF-7 cells. Findings revealed that $\mathrm{ZnO}$ nanorods triggered apoptosis via an intrinsic mitochondrial route that was dependent on caspase activation [169]. Similarly, another study using $\mathrm{ZnO}$ nanorods synthesized from Leea asiatica plant extract against MCF-7 cancer cells reported similar findings [170].

In a recent report, $\mathrm{ZnO}$ NPs prepared from stem bark extracts of Albizia lebbeck were also evaluated for their anticancerous activity against the MCF-7 cell line. Cytotoxicity and induction of membrane blebs was found against strong (MDA-MB 231) and weak (MCF-7) metastatic breast cancer cell lines in a dose-dependent action and on comparison with $0.05 \mathrm{M}$ and $0.01 \mathrm{M} \mathrm{NPs}$, the $0.1 \mathrm{M}$ ZnO NPs showed the best biological activity [171]. Similarly, biocompatible $\mathrm{ZnO}$ nanostructures were prepared from fruit extract of Vateria indicia (VI) with an average size of not more than $32 \mathrm{~nm}$, and their cytotoxicity was assessed on human triple-negative breast cancer (MDA-MB468). ZnO-VI nanostructures suppressed human triple-negative breast cancer up to $91.18 \pm 1.98 \%$ by promoting the generation of ROS via oxidative stress [172]. Likewise, ZnO NPs were synthesized from the leaves of Cynara scolymus. This plant is also well known to possess a wide range of compounds such as luteolin, glycosides, and apigenin [173]. Results showed that the synthesized ZnO NPs showed potential cytotoxicity against MCF-7 cells by causing apoptosis via enhanced oxidative stress and mitochondrial damage. They were also shown to reduce tumors associated with the liver, spleen, and kidney [174]. In another study, MCF-7 and VERO cell lines were exposed to spherical shaped ZnO NPs having a diameter of $65.9 \mathrm{~nm}$. Anti-proliferative capability was found due to the induction of apoptosis and thus can be considered safe in development of treatment methods [175]. Hence, it can be concluded that the plant-mediated $\mathrm{ZnO}$ NPs could be the most efficient anticancerous agents due to their strong therapeutic potential and low systemic toxicity.

Apoptosis is a sort of controlled cell death that is one of the most popular ways for anticancer medications to generate cytotoxicity [148,176]. Several intracellular and extracellular factors have been found to activate an apoptotic cascade, including the generation of ROS, serum starvation, and ionizing radiation [177,178]. Mitochondria, the largest generator of ROS [177], are considered to be an active molecule in cell death pathways. DNA damage by ROS triggers p53. It is thus stated that ROS production by mitochondria is associated with apoptosis caused by p53 [179]. According to a study, PEG coated $\mathrm{ZnO}$ NPs are considered to be more stable than ZnO NPs alone. The anticancerous activity of both types of ZnO NPs was evaluated in this study and the results showed that the PEG coated ZnO NP-induced death in breast cancer cells by generating ROS and blocking the repair pathway at the same time, with low damage to normal cells as compared to naked ZnO NPs [180]. Similarly, a novel method of synthesizing ZnO NPs using egg albumin (EA) was employed and its anticancer performance on MCF-7 cells was evaluated. EA-ZnO NPs with a diameter of 20-60 nm induced ROS and upregulated p53, caspase 3, and caspase 9 while down-regulating Bcl-2 (an anti-apoptotic gene), resulting in cytotoxicity [181]. Thus, elevating apoptosis-inducing markers could be of potential importance in treating cancer.

\subsection{Osteosarcoma}

Osteosarcoma is a cancerous tumor that mostly affects the long bones, although it can also affect other bones in the body. It has a bimodal distribution with maxima in 
late adulthood and the second decade of life [182]. Osteosarcoma is characterized by nonspecific symptoms, the most prevalent of which are new-onset, strain-related pain lasting many months and sleep disruption due to pain [183]. Cancer deaths owing to malignant neoplasms of the bones and joints account for $8.9 \%$ of total cancer deaths in children and adolescents. The current treatment of osteosarcoma is complicated due to the high risk of local relapse in a large number of patients after chemotherapy [184]. Thus, there is a rapid need to develop anticancer agents with high specificity and low toxicity. Rehmanniae Radix (RR) is a nontoxic herbal remedy that is widely used in China [185]. Recently, a study was conducted in which ZnO NPs were synthesized from RR and their anticancerous activity was evaluated against the osteosarcoma cell line (MG-63). The proposed work showed that the supplementation of ZnO NPs on MG-63 cells triggered excessive generation of ROS, which led to an alteration in MMP and thus resulted in apoptosis. Induction of apoptosis and inhibition of metastasis against MG-63 cells by $\mathrm{ZnO}$ NPs might be inherited from RR, which is a rich source of bioactive compounds [186].

Alhagi maurorum is another important medicinal herb with a wide range of pharmaceutical uses [187]. Various components of A. maurorum and its products have been employed to cure various ailments, such as cancer, dropsy, asthma, bronchitis, and many others $[188,189]$. Thus, $\mathrm{ZnO}$ NPs were green synthesized using leaf extract of A. maurorum and were evaluated against several cell lines of osteosarcoma. Results showed that the ZnO NPs demonstrated anti-tumor osteosarcoma activity against HOS, MG-63, G-292, clone A141B1, Saos-2, and Hs 707 (A) cell lines in a dose-dependent manner, with minimal cytotoxicity to the normal cell line (HUVEC). By increasing intracellular release of dissolved zinc ions, ZnO NPs produced cytotoxicity in cancer cells, which was followed by increased ROS generation and cancer cell death via the apoptosis signaling pathway [190].

\subsection{Colon Carcinoma}

Colon cancer is also one of the most common type of cancer worldwide, and it ranks alongside lung, prostate, and breast cancer as one of the main causes of death [191]. Colon cancer is more likely in men and women over the age of 65 years. People in this age bracket are affected by $75 \%$ of all incidence tumors [192]. ZnO NPs, like other types of cancer treatments, also play its positive role in treating colon cancer. Plantmediated $\mathrm{ZnO}$ NPs proved to be more efficient in treating colon cancer as compared to conventionally synthesized ZnO NPs due to their capping of phyto-chemicals. The activity of phyto-constituents against carcinogens could be mediated via the generation of ROS, which are implicated in phagocytosis, cell proliferation regulation, and intracellular signaling [193]. Deverra tortusa has gained attention in recent years due to the presence of several bioactive compounds such as flavonoids, glycosides, and terpenoids. The compounds are pharmacologically utilized in to treat asthma, hepatitis, and to regulate menstruation [194,195]. ZnO NPs prepared from aerial parts of Deverra tortusa were assessed against human colon adenocarcinoma (Caco-2) and A549 cell line. By inducing ROS, ZnO NPs displayed cytotoxicity against these two cell lines, whereas normal human lung fibroblast cell line (WI38) showed no significant cytotoxicity [193]. Similarly, reduced proliferation of Caco-2 cells was observed when exposed to ZnO NPs synthesized from Arthrospira platensis, whereas less toxicity was observed on the normal (WI38) cell line [196]. Likewise, selective toxicity was observed against HT-29 cell line on exposing ZnO NPs synthesized from rhizome extract of Bergenia ciliata [197].

Under normal circumstances, mitochondria create and release low quantities of ROS into the cytosol, which may act as signaling molecules for cell survival [198]. Intracellular NPs, on the other hand, cause cells to produce excessive amounts of ROS beyond the capacity of natural antioxidant defense mechanisms such as reductive GSH and antioxidant enzymes, resulting in cell death [199]. Compared to $\mathrm{TiO}_{2}, \mathrm{SiO}_{2}, \mathrm{ZrO}_{2}$, and carbon black nanomaterials, ZnO NPs cause much higher oxidative damage [199]. In a recent report, Caco-2 cells were exposed to silver and ZnO NPs to evaluate their respective cytotoxicity and it was found that ZnO NPs exert higher toxicity in comparison with silver NPs by 
elevating the levels of ROS [200]. Phyto-derived ZnO NPs from Spondias pinnata were evaluated on colon carcinoma (HCT-116) and chronic myelogenous leukemic (K562), along with normal lymphocytes/erythrocytes. Both phyto and chemically derived ZnO NPs were assessed in parallel and were hexagonal in shape and had an average size of 30 and $48.5 \mathrm{~nm}$, respectively. Phyto-derived ZnO NPs showed cytotoxicity against both the cell lines, while the one derived chemically were toxic only on HCT-116 cells. Apoptosis was observed to be induced by oxidative stress, elevating levels of ROS and promoting loss of MMP. No deleterious effects were observed in cells exposed to phyto-derived $\mathrm{ZnO}$ NPs, whereas toxicity was induced on cells exposed to chemically derived ZnO NPs [201]. Likewise, biocompatible ZnO NPs synthesized from Silybum marianum showed cytotoxic activity against the hepato-cellular carcinoma (HepG2) human cells [202].

\subsection{Cervical Cancer}

Cervical cancer is the fourth most common female malignancy worldwide, and it poses a significant global health challenge [203]. Every year, more than 500,000 women are diagnosed with cervical cancer, and the illness kills over 300,000 people globally. In most cases, high-risk subtypes of the human papillomavirus (HPV) cause this disease. The general prognosis for women with metastatic or recurrent illness remains poor [204]. According to studies, NPs synthesized using a green approach could be applied to cure cancer sufferers in the near future with minimal toxicity. They are chosen for their inherent capacity to penetrate tissue and cells, as well as their propensity to interact with malignant cells $[205,206]$. A study published showed the reaction of exposing ZnO NPs to human cervical cancer (Hela) cell lines synthesized from Abutilon indicum L. Results showed the cytotoxicity of ZnO NPs by selectively killing cancer cells through the production of ROS via the p53 pathway [207]. Likewise, rhizome extract of Bergenia ciliata was also employed to prepare ZnO NPs which showed a remarkable selective cytotoxicity against the Hela cell line, reducing cell viability at significant rates [197].

Various types of $\mathrm{ZnO}$ nanostructures have also been used for treating cancer. In a recent study, novel $\mathrm{ZnO}$ nanostructures were tested for their anticancerous activity against Hela and normal HEK cell lines. Growth inhibition and cell death were boosted in a dose-dependent manner in the Hela cell line as compared to the normal HEK cell line. Cell death was mainly induced by the increase in the formation of micronuclei, and these nanostructures might interfere with the rejoining of DNA strand breaks. Thus, $\mathrm{ZnO}$ nanostructures exhibited potent cytotoxicity against Hela cell lines and to some extent to normal cells, at all tested concentrations [208].

\subsection{Other Cancers}

Human multiple myeloma (MM) is a malignant and incurable tumor of the B cell. Anemia, renal failure, immunodeficiency, infection, and hypercalcemia are the most common clinical symptoms of MM patients [209,210]. MM remains an incurable hematological cancer, and pharmacological therapy continues to face the obstacles of drug resistance [211] and adverse side effects [212]. As a result, one of the most significant tasks in myeloma therapy research is to overcome drug resistance in myeloma cells and to develop low-toxicity, high-efficiency medications. Hence, a study was designed to investigate the effects of $\mathrm{ZnO}$ NPs on RPMI8226, a human myeloid derived cell line. The apoptosis assay confirmed cell death in a time and dose-dependent manner. Additionally, ZnO NPs also increased ROS production and decreased ATP levels in MM cells. Elevated expression of apoptotic markers Cyt-C, Apaf-1, caspase 3, and caspase 9 were also observed, which induced cell death. In contrast, little cytotoxicity was shown in peripheral blood mononuclear cells (PBMCs) [213].

Nanostructures are widely used in cell and molecular biology, tissue engineering, clinical bio-analytical diagnostics, and therapies as markers and probes [214]. Because of their cytotoxic nature, quantum dots have the ability to slow the growth of cancer cells. In a study, the activity of ZnO QDs was evaluated against myoblast cancer cells (C2C12). 
Inhibition of the growth of cancer cells was observed in a dose-dependent action. Reverse transcription (RT) polymerase chain reaction analysis showed upregulation in caspase 3/7 genes, responsible for inducing death [215].

Tongue cancer is among the most frequent cancers in the oral maxillofacial region, and recurrence is common even after surgery. The potential of ZnO NPs on human tongue cancer cells (CAL 27) was investigated in a study. The viability of CAL 27 cells was reduced as $\mathrm{ZnO} N P$ concentrations were increased. By elevating intracellular ROS levels and reducing MMP, ZnO NPs triggered PINK1/Parkin-mediated mitophagy in a time-dependent manner [216].

Natural plant extracts and their bio constituents provide environmentally acceptable biosynthetic techniques for various metal and metal oxide NPs, allowing for a regulated synthesis with tunable form and size [217]. Therefore, ZnO NPs were prepared from the leaves of Murraya keenigii and their potential towards treating gastric cancer cells (MGC 803) were evaluated in vitro. Significant toxicity was induced against MGC 803 cell lines, extending the scope of ZnO NPs in biomedicine [218]. Efficient antibacterial and anticancer activities were observed by curcumin and ZnO NPs used either alone or in combination. Thus, curcumin loaded $\mathrm{ZnO}$ nanocomposites were fabricated and evaluated against bacterial strains and rhabdomyosarcoma (RD) cell lines. Spherical ZnO-curcumin NPs (SZNPs-CS) exhibited an excellent effect showing low toxicity against normal cells and higher toxicity against RD cell lines along with development of inhibition zones against tested bacterial strains [219]. Marsdenia tenacissima, a Chinese medicinal herb, has long been utilized as a clinical treatment for many types of cancers. ZnO NPs were prepared using extracts of $M$. tenacissima and were evaluated against the laryngeal cancer cell line Hep-2 in vitro. $\mathrm{ZnO} N P$ s were able to successfully generate ROS, alter MMP, and promote nuclear damage. RT-PCR analysis confirmed the upregulation of Bax, caspase 3, and caspase 9 while down-regulating Bcl-2. Thus, $M$. tenacissima mediated $\mathrm{ZnO}$ NPs could be a viable anticancer approach for treating a variety of cancers [117].

Ovarian cancer remains the most fatal of all gynecological cancers and the leading cause of cancer-related mortality in women. Oxidative and proteotoxic stress by ZnO NPs initiating apoptosis was evaluated on ovarian cancer cell lines and it was demonstrated that their viability considerably dropped with increased cytotoxicity as the size of NPs decreased [220]. In a study, the cytotoxic effect of ZnO NPs was investigated on human ovarian cancer cells (SKOV 3). According to the findings, ZnO NPs can cause significant cytotoxicity, apoptosis, and autophagy in human ovarian cells via producing ROS and oxidative stress [221].

The generation of ROS such as peroxide, hydroxyl radicals, and superoxide is strongly linked to cancer cell apoptosis [222,223]. As a result, gaining a better knowledge of the influence of ROS will lead to the development of viable strategies for developing novel and successful cancer medicines [224]. Oxidative stress caused by well-crystallized $\mathrm{ZnO}$ NPs was evaluated on Cloudman S91 melanoma cancer cells. Hexagonal ZnO NPs with an average size of $10 \mathrm{~nm}$ successfully induce the production of ROS causing apoptosis with varying doses of $\mathrm{ZnO} N P s$ [120]. Similarly, another research project looked into the effects of ZnO NPs on human gingival squamous cell cancer (GSCC). The inhibited growth of ZnO NPs was investigated against Ca9-22 and OECM-1 cell lines. Results predicted the selective anticancerous effects of ZnO NPs on GSCC by generating ROS and disrupting MMP, which leads to apoptosis through caspase-dependent pathways. Human normal keratinocytes ( $\mathrm{HaCaT}$ cells) and gingival fibroblasts, on the other hand, appeared to be less affected by $\mathrm{ZnO}$ NPs [225].

Recently, $\mathrm{ZnO}$ nanostructures induced apoptosis in a dose-dependent manner in a human brain tumor (U87), confirmed via MTT assay [208]. Likewise, inorganic ZnO NPs were synthesized by a co-precipitation method and were evaluated in leukemia (K562) cells. ZnO NPs showed an inhibitory effect on K562 cell proliferation while being safe for lymphocyte normal cells [226]. In another study, varied murine cancer cell lines (CT-26, 4T1, CRL-1451, and WEHI-3) as well as a normal mouse fibroblast cell line (3T3) were 
also treated with different concentrations of $\mathrm{ZnO}$ NPs. The anti-proliferative effects were found and confirmed using the MTT assay. However, no toxic effect was shown on normal fibroblast cell lines [227]. This confirms the potential role of ZnO NPs as a key player in cancer therapies.

Table 2. Anticancerous activity of ZnO NPs on different types of cancer cell lines.

\begin{tabular}{|c|c|c|c|c|c|c|c|}
\hline $\begin{array}{l}\text { Method of } \\
\text { Synthesis of } \\
\text { ZnO NPs }\end{array}$ & $\begin{array}{l}\text { Morphology/ } \\
\text { Structure }\end{array}$ & Size (nm) & $\begin{array}{l}\text { Exposure } \\
\text { Time }\end{array}$ & Cancer Type & Cell Line & $\mathrm{IC}_{50}$ Value & References \\
\hline $\begin{array}{l}\text { Chemical } \\
\text { method }\end{array}$ & Polygonal & $21 \mathrm{~nm}$ & $24 \mathrm{~h}$ & \multirow{8}{*}{ Liver cancer } & HepG2 & $10-15 \mu \mathrm{g} / \mathrm{mL}$ & {$[40]$} \\
\hline- & & $30 \mathrm{~nm}$ & $12,24 \mathrm{~h}$ & & HepG2 & $14.5 \mu \mathrm{g} / \mathrm{mL}$ & [125] \\
\hline $\begin{array}{l}\text { Biological } \\
\text { method }\end{array}$ & & $20-40 \mathrm{~nm}$ & $\begin{array}{l}72 \mathrm{~h}, 24, \\
\text { and } 48 \mathrm{~h}\end{array}$ & & $\begin{array}{l}\text { HepG2 and } \\
\text { HUH7 }\end{array}$ & $\begin{array}{l}40 \mu \mathrm{g} / \mathrm{mL}, 17.5 \\
\text { and } 15 \mu \mathrm{g} / \mathrm{mL}\end{array}$ & {$[134]$} \\
\hline $\begin{array}{l}\text { Biological } \\
\text { method }\end{array}$ & Spherical & $90 \mathrm{~nm}$ & $24 \mathrm{~h}$ & & HepG2 & - & [118] \\
\hline $\begin{array}{c}\text { Biological } \\
\text { method }\end{array}$ & Multi-shaped & $96-110 \mathrm{~nm}$ & $24 \mathrm{~h}$ & & HepG2 & - & [41] \\
\hline $\begin{array}{l}\text { Biological } \\
\text { method }\end{array}$ & Hexagonal & $18 \mathrm{~nm}$ & $48 \mathrm{~h}$ & & HepG2 & $39.26 \mu \mathrm{g} / \mathrm{mL}$ & {$[42]$} \\
\hline $\begin{array}{l}\text { Biological } \\
\text { method }\end{array}$ & - & - & $48 \mathrm{~h}$ & & HepG2 & $150 \mu \mathrm{g} / \mathrm{mL}$ & {$[141]$} \\
\hline- & - & $50 \mathrm{~nm}$ & $\begin{array}{c}24 \text { and } \\
48 \mathrm{~h}\end{array}$ & & HepG2 & $\begin{array}{c}2.22 \text { and } \\
1.54 \mu \mathrm{g} / \mathrm{mL}\end{array}$ & {$[228]$} \\
\hline $\begin{array}{l}\text { Chemical } \\
\text { method }\end{array}$ & Hexagonal & $50-70 \mathrm{~nm}$ & $24 \mathrm{~h}$ & \multirow{4}{*}{ Lung cancer } & A549 & $50 \mu \mathrm{g} / \mathrm{mL}$ & [149] \\
\hline $\begin{array}{l}\text { Biological } \\
\text { method }\end{array}$ & $\begin{array}{l}\text { Hexagonal } \\
\text { wurtzite }\end{array}$ & $60 \mathrm{~nm}$ & - & & A549 & - & [152] \\
\hline $\begin{array}{l}\text { Biological } \\
\text { method }\end{array}$ & $\begin{array}{l}\text { Spherical and } \\
\text { hexagonal }\end{array}$ & $209 \mathrm{~nm}$ & $48 \mathrm{~h}$ & & A549 & $40 \mu \mathrm{g} / \mathrm{mL}$ & [153] \\
\hline $\begin{array}{l}\text { Biological } \\
\text { method }\end{array}$ & Spherical & $90 \mathrm{~nm}$ & $24 \mathrm{~h}$ & & A549 & - & [118] \\
\hline $\begin{array}{l}\text { Biological } \\
\text { method }\end{array}$ & - & - & $24 \mathrm{~h}$ & \multirow{12}{*}{ Breast cancer } & MCF-7 & $121 \mu \mathrm{g} / \mathrm{mL}$ & [119] \\
\hline $\begin{array}{l}\text { Biological } \\
\text { method }\end{array}$ & Spherical & $90 \mathrm{~nm}$ & $24 \mathrm{~h}$ & & MCF-7 & - & [118] \\
\hline $\begin{array}{l}\text { Chemical } \\
\text { method }\end{array}$ & Round & $10-15 \mathrm{~nm}$ & $48 \mathrm{~h}$ & & MCF-7 & $15.88 \mu \mathrm{g} / \mathrm{mL}$ & {$[158]$} \\
\hline $\begin{array}{l}\text { Biological } \\
\text { method }\end{array}$ & Spherical & $40 \mathrm{~nm}$ & $24 \mathrm{~h}$ & & MCF-7 & $40 \mu \mathrm{g} / \mathrm{mL}$ & [159] \\
\hline $\begin{array}{c}\text { Biological } \\
\text { method }\end{array}$ & - & $32.5 \mathrm{~nm}$ & $24 \mathrm{~h}$ & & $\begin{array}{c}\text { MCF-7 and } \\
\text { TUBO }\end{array}$ & 40 and $33 \mu \mathrm{g} / \mathrm{mL}$ & [160] \\
\hline $\begin{array}{l}\text { Biological } \\
\text { method }\end{array}$ & Spherical & $40 \mathrm{~nm}$ & $72 \mathrm{~h}$ & & $\begin{array}{c}\text { MCF-7, } \\
\text { MDA-MB231 }\end{array}$ & $\begin{array}{r}23.8 \mu \mathrm{g} / \mathrm{mL} \\
41.354 \mu \mathrm{g} / \mathrm{mL}\end{array}$ & {$[161]$} \\
\hline $\begin{array}{l}\text { Biological } \\
\text { method }\end{array}$ & Spherical & $81.1 \mathrm{~nm}$ & $24 \mathrm{~h}$ & & MCF-7 & $36 \mu \mathrm{g} / \mathrm{mL}$ & [165] \\
\hline $\begin{array}{c}\text { Biological } \\
\text { method }\end{array}$ & $\begin{array}{l}\text { Face centered } \\
\text { cubic }\end{array}$ & $30.2 \mathrm{~nm}$ & $24 \mathrm{~h}$ & & MCF-7 & $32.8 \mu \mathrm{g} / \mathrm{mL}$ & [166] \\
\hline $\begin{array}{l}\text { Biological } \\
\text { method }\end{array}$ & $\begin{array}{l}\text { Hexagonal } \\
\text { wurtzite }\end{array}$ & $32 \mathrm{~nm}$ & $24 \mathrm{~h}$ & & MCF-7 & $6.84 \mu \mathrm{g} / \mathrm{mL}$ & {$[167]$} \\
\hline $\begin{array}{l}\text { Biological } \\
\text { method }\end{array}$ & - & - & $24 \mathrm{~h}$ & & MCF-7 & $58.87 \mu \mathrm{g} / \mathrm{mL}$ & {$[168]$} \\
\hline $\begin{array}{l}\text { Biological } \\
\text { method }\end{array}$ & Rod & $100 \mathrm{~nm}$ & $48 \mathrm{~h}$ & & MCF-7 & $10 \mu \mathrm{g} / \mathrm{mL}$ & [169] \\
\hline $\begin{array}{c}\text { Biological } \\
\text { method }\end{array}$ & Multi-shaped & $66.25 \mathrm{~nm}$ & $24 \mathrm{~h}$ & & $\begin{array}{c}\text { MCF-7, } \\
\text { MDA-MB } 231\end{array}$ & - & {$[171]$} \\
\hline
\end{tabular}


Table 2. Cont.

\begin{tabular}{|c|c|c|c|c|c|c|c|}
\hline $\begin{array}{l}\text { Method of } \\
\text { Synthesis of } \\
\text { ZnO NPs }\end{array}$ & $\begin{array}{l}\text { Morphology/ } \\
\text { Structure }\end{array}$ & Size (nm) & $\begin{array}{l}\text { Exposure } \\
\text { Time }\end{array}$ & Cancer Type & Cell Line & $\mathrm{IC}_{50}$ Value & References \\
\hline $\begin{array}{l}\text { Biological } \\
\text { method }\end{array}$ & Spherical & $65.9 \mathrm{~nm}$ & - & & MCF-7 & $65.31 \mu \mathrm{g} / \mu \mathrm{L}$ & [175] \\
\hline $\begin{array}{l}\text { Chemical } \\
\text { method }\end{array}$ & $\begin{array}{l}\text { Spherical and } \\
\text { hexagonal }\end{array}$ & $20-60 \mathrm{~nm}$ & $24 \mathrm{~h}$ & & MCF-7 & $100 \mu \mathrm{g} / \mathrm{mL}$ & [181] \\
\hline $\begin{array}{l}\text { Chemical } \\
\text { method }\end{array}$ & Tetragonal & $30-40 \mathrm{~nm}$ & $48 \mathrm{~h}$ & & MCF-7 & $33.06 \mu \mathrm{g} / \mathrm{mL}$ & {$[174]$} \\
\hline $\begin{array}{l}\text { Biological } \\
\text { method }\end{array}$ & $\begin{array}{l}\text { Hexagonal } \\
\text { wurtzite }\end{array}$ & $10-12 \mathrm{~nm}$ & $24 \mathrm{~h}$ & & MG-63 & - & [186] \\
\hline $\begin{array}{l}\text { Biological } \\
\text { method }\end{array}$ & Spherical & $27.92 \mathrm{~nm}$ & - & Bone cancer & $\begin{array}{l}\text { HOS, MG-63, } \\
\text { G-292 clone } \\
\text { A141B1, Saos-2, } \\
\text { Hs 707(A) }\end{array}$ & $\begin{array}{l}234,285,327,372 \\
\quad 341 \mu \mathrm{g} / \mathrm{mL}\end{array}$ & [190] \\
\hline $\begin{array}{l}\text { Biological } \\
\text { method }\end{array}$ & Hexagonal & $15.22 \mathrm{~nm}$ & - & \multirow{4}{*}{ Colon cancer } & Caco-2 & $50.81 \mu \mathrm{g} / \mathrm{mL}$ & [193] \\
\hline $\begin{array}{l}\text { Biological } \\
\text { method }\end{array}$ & Spherical & $30-55 \mathrm{~nm}$ & $48 \mathrm{~h}$ & & Caco-2 & 9.95 ppm & [196] \\
\hline $\begin{array}{l}\text { Chemical } \\
\text { method }\end{array}$ & $\begin{array}{l}\text { Hexagonal } \\
\text { wurtzite }\end{array}$ & $30 \mathrm{~nm}$ & $48 \mathrm{~h}$ & & НCТ-116 & $60 \mu \mathrm{g} / \mathrm{mL}$ & [201] \\
\hline $\begin{array}{l}\text { Biological } \\
\text { method }\end{array}$ & Flower shaped & $30 \mathrm{~nm}$ & $48 \mathrm{~h}$ & & НТ-29 & $124.3 \mu \mathrm{g} / \mathrm{mL}$ & [197] \\
\hline $\begin{array}{l}\text { Biological } \\
\text { method }\end{array}$ & Spherical & $50-500 \mathrm{~nm}$ & $24 \mathrm{~h}$ & \multirow{3}{*}{ Cervical cancer } & Hela & $45.82 \mu \mathrm{g} / \mathrm{mL}$ & [207] \\
\hline $\begin{array}{l}\text { Biological } \\
\text { method }\end{array}$ & Flower shaped & $30 \mathrm{~nm}$ & $48 \mathrm{~h}$ & & Hela & $101.7 \mu \mathrm{g} / \mathrm{mL}$ & [197] \\
\hline $\begin{array}{l}\text { Chemical } \\
\text { method }\end{array}$ & $\begin{array}{l}\text { Flower and } \\
\text { hexagonal }\end{array}$ & 20-30 nm & $48 \mathrm{~h}$ & & Hela & $9.2-128 \mu \mathrm{g} / \mathrm{mL}$ & [208] \\
\hline- & Spherical & $30 \mathrm{~nm}$ & $24 \mathrm{~h}$ & $\begin{array}{l}\text { Human } \\
\text { multiple } \\
\text { myeloma }\end{array}$ & RPMI8226 & $33.83 \mu \mathrm{g} / \mathrm{mL}$ & [213] \\
\hline $\begin{array}{l}\text { Chemical } \\
\text { method }\end{array}$ & Spherical & $7-8 \mathrm{~nm}$ & $24 \mathrm{~h}$ & $\begin{array}{l}\text { Myoblast } \\
\text { cancer }\end{array}$ & $\mathrm{C} 2 \mathrm{C} 12$ & - & {$[215]$} \\
\hline- & Hexagonal & $30 \mathrm{~nm}$ & $24 \mathrm{~h}$ & Oral cancer & CAL 27 & $25 \mu \mathrm{g} / \mathrm{mL}$ & {$[216]$} \\
\hline $\begin{array}{l}\text { Biological } \\
\text { method }\end{array}$ & Spherical & $20 \mathrm{~nm}$ & $24 \mathrm{~h}$ & Gastric cancer & MGC803 & - & [218] \\
\hline $\begin{array}{l}\text { Chemical } \\
\text { method }\end{array}$ & Spherical & $40-100 \mathrm{~nm}$ & $24 \mathrm{~h}$ & \multicolumn{2}{|c|}{$\begin{array}{l}\text { Rhabdomyosarcoma } \\
\text { cell line }\end{array}$} & $13 \mu \mathrm{g} / \mathrm{mL}$ & [219] \\
\hline $\begin{array}{l}\text { Biological } \\
\text { method }\end{array}$ & Spherical & - & $24 \mathrm{~h}$ & $\begin{array}{l}\text { Laryngeal } \\
\text { cancer }\end{array}$ & Hep-2 & $7.5 \mu \mathrm{g} / \mathrm{mL}$ & [117] \\
\hline $\begin{array}{l}\text { Chemical } \\
\text { method }\end{array}$ & $\begin{array}{l}\text { Flower and } \\
\text { hexagonal }\end{array}$ & $20-30 \mathrm{~nm}$ & $48 \mathrm{~h}$ & $\begin{array}{l}\text { Human brain } \\
\text { tumor }\end{array}$ & U87 & $9.2-128 \mu \mathrm{g} / \mathrm{mL}$ & [208] \\
\hline $\begin{array}{l}\text { Chemical } \\
\text { method }\end{array}$ & Spherical & $10 \mathrm{~nm}$ & $24 \mathrm{~h}$ & \multirow{2}{*}{ Ovarian cancer } & SKOV3 & - & {$[220]$} \\
\hline- & $\begin{array}{l}\text { Hexagonal } \\
\text { wurtzite }\end{array}$ & $20 \mathrm{~nm}$ & $24 \mathrm{~h}$ & & SKOV3 & - & {$[221]$} \\
\hline $\begin{array}{l}\text { Chemical } \\
\text { method }\end{array}$ & Hexagonal & $10 \mathrm{~nm}$ & $24 \mathrm{~h}$ & $\begin{array}{l}\text { Melanoma } \\
\text { cancer }\end{array}$ & Cloudman S91 & - & {$[120]$} \\
\hline $\begin{array}{l}\text { Chemical } \\
\text { method }\end{array}$ & - & - & $24 \mathrm{~h}$ & $\begin{array}{c}\text { Human } \\
\text { gingival } \\
\text { squamous cell } \\
\text { carcinoma }\end{array}$ & $\begin{array}{l}\text { Ca9-22 and } \\
\text { OECM-1 }\end{array}$ & $\begin{array}{c}17.4 \mu \mathrm{g} / \mathrm{mL} \text { and } \\
51.0 \mu \mathrm{g} / \mathrm{mL}\end{array}$ & {$[225]$} \\
\hline $\begin{array}{l}\text { Biological } \\
\text { method }\end{array}$ & $\begin{array}{l}\text { Hexagonal } \\
\text { wurtzite }\end{array}$ & $10-15 \mathrm{~nm}$ & $72 \mathrm{~h}$ & $\begin{array}{l}\text { Murine cancer } \\
\text { cells }\end{array}$ & $\begin{array}{c}\text { 4T1, CRL-1451, } \\
\text { CT-26, } \\
\text { WEHI-3B }\end{array}$ & $\begin{array}{l}21.7,17.45,11.75 \\
\quad 5.6 \mu \mathrm{g} / \mathrm{mL}\end{array}$ & {$[227]$} \\
\hline
\end{tabular}




\section{Mechanism Involved in Anticancerous Activity of ZnO NPs via Apoptosis Pathway}

Formation of intracellular ROS is believed to be linked to the mitochondrial electron transport chain and it is believed that the anticancerous agents that invade cancer cells could also damage the electron transport chain, resulting in a massive release of ROS intracellularly $[229,230]$. Thus, elevating levels of ROS results in mitochondrial damage followed by a loss in balance of protein activities, ultimately leading to apoptosis [231]. $\mathrm{ZnO} N P s$, therefore, present cytotoxicity in cancer cells due to the increased intracellular levels of dissolved zinc ions, followed by enhanced ROS production, causing cancer cell death via an apoptotic signaling pathway [232].

Figure 5 represents the possible mechanism involved in the anticancerous activity of $\mathrm{ZnO}$ NPs. Cancer cells can uptake the ZnO NPs by an endocytic route, and this entry route may differ depending upon the cell type involved. Confinement of $\mathrm{ZnO} N P s$ to vesicular structures, endosomes and then finally to lysosomes is due to the energy-dependent processes of NP uptake. Acidic $\mathrm{pH}$ of lysosomes may trigger the cytosolic release of $\mathrm{ZnO} N P s$ and $\mathrm{Zn}^{2+}$ ions, selectively inducing toxicity, thereby, causing apoptosis, necrosis, cell cycle arrest, and membrane damage by excessive ROS production. Entrance of $\mathrm{Zn}^{2+}$ ions may also take place through ion channels suppressing the activity of Bcl-2 markers (anti-apoptotic proteins), which in turn induces the expression of Bak/Bax (pro-apoptotic proteins) to promote permeabilization, followed by release of cytochrome c. Formation of a complex combining cytochrome c, along with apoptotic protease activating factor (Apaf-1) and pro-caspase 9, activates the Apoptosome. Activation of caspase 9 triggers caspase 3 and 7 gene expression and activity, which ultimately leads to apoptosis of cancer cells.

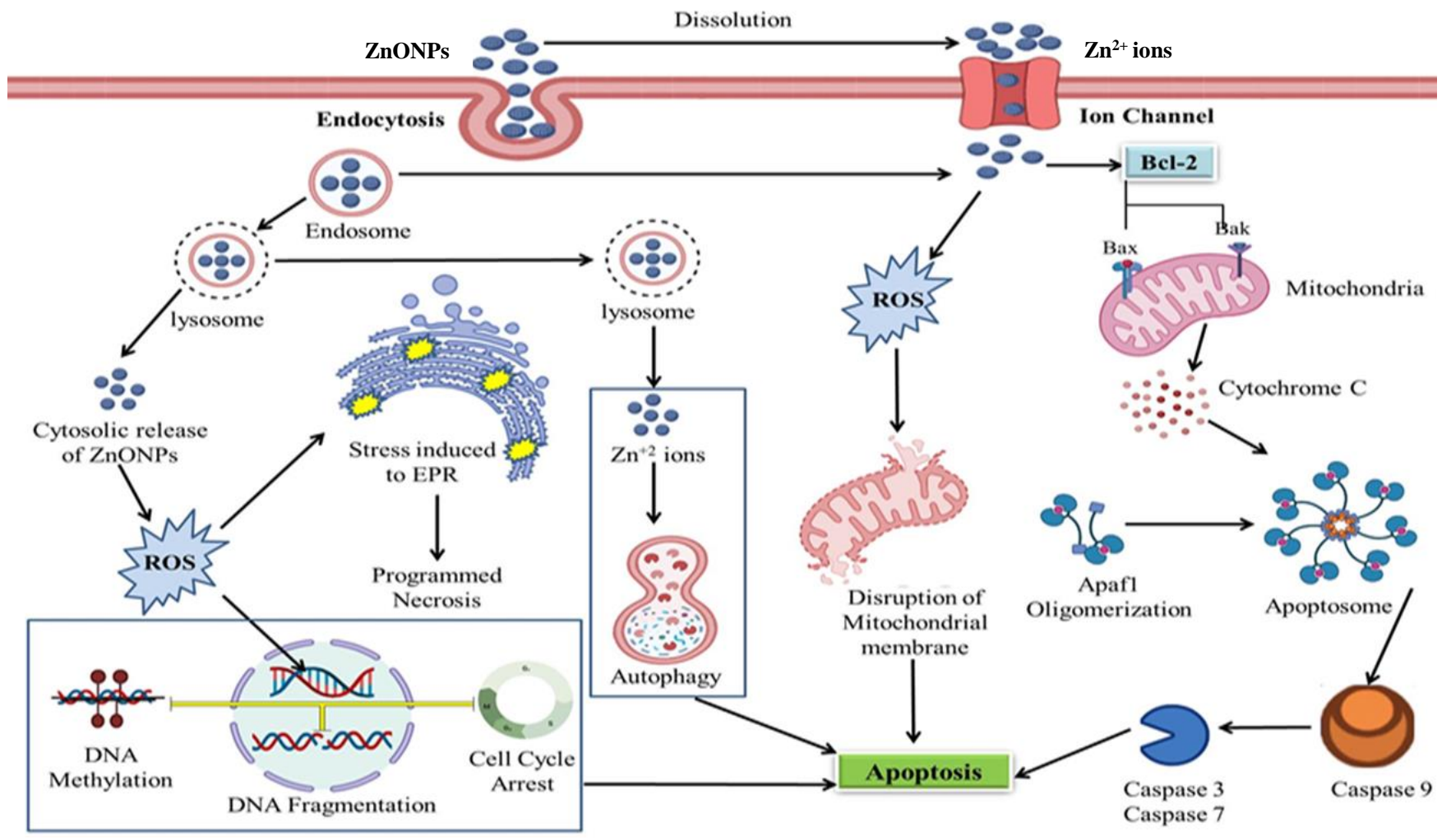

Figure 5. Possible mechanism involved in anticancerous activity of ZnO NPs.

\section{Conclusions and Future Prospects}

Despite significant advancements in the field of diagnosis, sustained drug delivery and treatment of cancer, it continues to be the leading cause of death worldwide. No effective treatment of cancer has been developed so far and all traditional therapies and medications are constrained by negative effects. Thus, researchers are striving to develop 
novel ways in order to generate better diagnostic devices and treatments that tend to have greater specificity and efficiency along with lower toxicity. In this time of hopelessness, nanotechnology has sparked hope that life-threatening diseases such as cancer will be efficiently treated in the near future. Higher retention period, tunable morphology, and lower rate of agglomeration are the major features of nanomaterials that have made them emerge so rapidly in the field of cancer theranostic.

Among metal oxide NPs, ZnO NPs have powerful inhibitory effects against malignant cells due to their inherent toxicity, which they achieve via causing intracellular ROS generation and activating the apoptotic signaling pathway, making them a suitable choice for anticancer medicines. Furthermore, when used as drug carriers, ZnO NPs have been shown to increase the bioavailability of therapeutic medicines or biomolecules, resulting in improved therapy efficiency. This review comprehensively represents the therapeutic potential of $\mathrm{ZnO}$ NPs against numerous cancer cell lines both in vivo and in vitro along with their mechanisms of action. The effect of ZnO NPs differed among cancer types, demonstrating that, in addition to the unique features of ZnO NPs, the cellular response is crucial. ROS can thus be considered as a player molecule in triggering p53 pathways and caspase cascades, ultimately leading to apoptosis.

Despite the numerous applications, exposure to ZnO NPs poses a significant threat to human health and the ecosystem. Though ZnO NPs offer significant safety and biocompatibility, their unregulated and uncontrolled use may have intended consequences for the biological system. Considering the future potential of $\mathrm{ZnO}$ NPs, it is unavoidably necessary to have a better grasp of their toxicity. It is also believed that ZnO NPs would significantly advance medical progress and are predicted to make even more intriguing contributions in these domains. Although ZnO NPs have shown exceptional promise in the diagnosis and treatment of cancers, more in-depth and advanced analysis of ZnO NPs, detailed understanding of the cellular and molecular pathways, and clinical trials will be required in the future for better cancer theranostic.

Author Contributions: Conceptualization, S.A.; methodology, M.H., M.K., and S.A.M.; validation, J.M.L., C.H., B.H.A., and S.A.; formal analysis, S.A.; investigation, M.H. and S.A.M.; resources, C.H., B.H.A., and S.A.; data curation, J.M.L., C.H., B.H.A., and S.A.; writing-original draft preparation, M.H., M.K., and S.A.; writing-review and editing, S.A., J.M.L., C.H., and B.H.A.; supervision, S.A., B.H.A., and C.H.; project administration, S.A.; funding acquisition, C.H., B.H.A., and S.A. All authors have read and agreed to the published version of the manuscript.

Funding: We acknowledge funding from the ARD2020 Biopharmaceutical program of the Région Centre Val de Loire (ETOPOCentre project).

Data Availability Statement: All data are included in present study.

Conflicts of Interest: The authors declare no conflict of interest.

\section{References}

1. Bray, F.; Laversanne, M.; Weiderpass, E.; Soerjomataram, I. The ever-increasing importance of cancer as a leading cause of premature death worldwide. Cancer 2021, 127, 2864-2866.

2. Ferlay, J.; Ervik, M.; Lam, F.; Colombet, M.; Mery, L.; Piñeros, M.; Znaor, A.; Soerjomataram, I.; Bray, F. Global cancer observatory: Cancer today. Int. J. Cancer 2018, 144, 1941-1953. [CrossRef] [PubMed]

3. De Mesquita, M.L.; de Paula, J.E.; Pessoa, C.; de Moraes, M.O.; Costa-Lotufo, L.V.; Grougnet, R.; Michel, S.; Tillequin, F.; Espindola, L.S. Cytotoxic activity of Brazilian Cerrado plants used in traditional medicine against cancer cell lines. J. Ethnopharmacol. 2009, 123, 439-445. [CrossRef]

4. Mondal, A.; Bose, S.; Banerjee, S.; Patra, J.K.; Malik, J.; Mandal, S.K.; Kilpatrick, K.L.; Das, G.; Kerry, R.G.; Fimognari, C. Marine Cyanobacteria and Microalgae Metabolites-A Rich Source of Potential Anticancer Drugs. Mar. Drugs 2020, 18, 476. [CrossRef] [PubMed]

5. Kim, A. Mitochondria in cancer energy metabolism: Culprits or bystanders? Toxicol. Res. 2015, 31, 323-330. [CrossRef] [PubMed]

6. Marc, B. An Introduction to Cancer and Basic Cancer Vocabulary. Beth Publ. 2002, 38, 58-72.

7. Collins, K.; Jacks, T.; Pavletich, N.P. The cell cycle and cancer. Proc. Natl. Acad. Sci. USA 1997, 94, 2776-2778. [CrossRef]

8. Shen, Z. Genomic instability and cancer: An introduction. J. Mol. Cell Biol. 2011, 3, 1-3. [CrossRef]

9. Folkman, J. Tumor angiogenesis: Therapeutic implications. N. Engl. J. Med. 1971, 285, 1182-1186. [PubMed] 
10. Anand, P.; Kunnumakara, A.B.; Sundaram, C.; Harikumar, K.B.; Tharakan, S.T.; Lai, O.S.; Sung, B.; Aggarwal, B.B. Cancer is a preventable disease that requires major lifestyle changes. Pharm. Res. 2008, 25, 2097-2116. [CrossRef] [PubMed]

11. Hejmadi, M. Introduction to Cancer Biology; Bookboon: London, UK, 2014.

12. Loeb, K.R.; Loeb, L.A. Significance of multiple mutations in cancer. Carcinogenesis 2000, 21, 379-385. [CrossRef] [PubMed]

13. Hahn, W.C.; Weinberg, R.A. Modelling the molecular circuitry of cancer. Nat. Rev. Cancer 2002, 2, 331-341. [CrossRef]

14. Mucci, L.; Wedren, S.; Tamimi, R.; Trichopoulos, D.; Adami, H.O. The role of gene-environment interaction in the aetiology of human cancer: Examples from cancers of the large bowel, lung and breast. J. Intern. Med. 2001, 249, 477-493. [CrossRef]

15. Czene, K.; Hemminki, K. Kidney cancer in the Swedish Family Cancer Database: Familial risks and second primary malignancies. Kidney Int. 2002, 61, 1806-1813. [CrossRef]

16. Shah, P.V.; Rajput, S. Surface Decorated Mesoporous Silica Nanoparticles: A Promising and Emerging Tool for Cancer Targeting. Indian J. Pharm. Educ. Res 2019, 53, 382-399. [CrossRef]

17. Liu, B.; Ezeogu, L.; Zellmer, L.; Yu, B.; Xu, N.; Joshua Liao, D. Protecting the normal in order to better kill the cancer. Cancer Med. 2015, 4, 1394-1403. [CrossRef]

18. Mousa, S.A.; Bharali, D.J. Nanotechnology-based detection and targeted therapy in cancer: Nano-bio paradigms and applications. Cancers 2011, 3, 2888-2903. [CrossRef]

19. Pillai, G. Nanotechnology toward treating cancer: A comprehensive review. Appl. Target. Nano Drugs Deliv. Syst. 2019, 9, 221-256.

20. Zivyar, N.; Bagherzade, G.; Moudi, M.; Manzari Tavakoli, M. Evaluation of the green synthesis, characterization and antibacterial activity of silver nanoparticles from corm extract of Crocus sativus var. Haussknechtii. J. Hortic. Postharvest Res. $2021,19-32$.

21. Ratan, Z.A.; Haidere, M.F.; Nurunnabi, M.; Shahriar, S.M.; Ahammad, A.; Shim, Y.Y.; Reaney, M.J.; Cho, J.Y. Green chemistry synthesis of silver nanoparticles and their potential anticancer effects. Cancers 2020, 12, 855. [CrossRef] [PubMed]

22. Vickers, A. Alternative cancer cures:"unproven" or "disproven"? Cancer J. Clin. 2004, 54, 110-118. [CrossRef]

23. Peer, D.; Karp, J.M.; Hong, S.; Farokhzad, O.C.; Margalit, R.; Langer, R. Nanocarriers as an emerging platform for cancer therapy. Nat. Nanotechnol. 2007, 2, 751-760. [CrossRef]

24. Muthu, M.S.; Feng, S.-S. Theranostic liposomes for cancer diagnosis and treatment: Current development and pre-clinical success. Expert Opin. Drug Deliv. 2013, 10, 151-155. [CrossRef] [PubMed]

25. Zhao, M.-X.; Zhu, B.-J.; Yao, W.-J.; Chen, D.-F. Therapeutic effect of quantum dots for cancer treatment. RSC Adv. 2016, 6 , 113791-113795. [CrossRef]

26. Fabbro, C.; Ali-Boucetta, H.; Da Ros, T.; Kostarelos, K.; Bianco, A.; Prato, M. Targeting carbon nanotubes against cancer. Chem. Commun. 2012, 48, 3911-3926. [CrossRef] [PubMed]

27. Varela-Moreira, A.; Shi, Y.; Fens, M.H.; Lammers, T.; Hennink, W.E.; Schiffelers, R.M. Clinical application of polymeric micelles for the treatment of cancer. Mater. Chem. Front. 2017, 1, 1485-1501. [CrossRef]

28. Mukerjee, A.; Vishwanatha, J.K. Formulation, characterization and evaluation of curcumin-loaded PLGA nanospheres for cancer therapy. Anticancer Res. 2009, 29, 3867-3875. [PubMed]

29. Smijs, T.G.; Pavel, S. Titanium dioxide and zinc oxide nanoparticles in sunscreens: Focus on their safety and effectiveness. Nanotechnol. Sci. Appl. 2011, 4, 95. [CrossRef]

30. Ruszkiewicz, J.A.; Pinkas, A.; Ferrer, B.; Peres, T.V.; Tsatsakis, A.; Aschner, M. Neurotoxic effect of active ingredients in sunscreen products, a contemporary review. Toxicol. Rep. 2017, 4, 245-259. [CrossRef]

31. Vidor, F.F.; Meyers, T.; Müller, K.; Wirth, G.I.; Hilleringmann, U. Inverter circuits on freestanding flexible substrate using ZnO nanoparticles for cost-efficient electronics. Solid-State Electron. 2017, 137, 16-21. [CrossRef]

32. Vasantharaj, S.; Sathiyavimal, S.; Senthilkumar, P.; Kalpana, V.; Rajalakshmi, G.; Alsehli, M.; Elfasakhany, A.; Pugazhendhi, A. Enhanced photocatalytic degradation of water pollutants using bio-green synthesis of zinc oxide nanoparticles (ZnO NPs). J. Environ. Chem. Eng. 2021, 105772. [CrossRef]

33. Brintha, S.; Ajitha, M. Synthesis and characterization of $\mathrm{ZnO}$ nanoparticles via aqueous solution, sol-gel and hydrothermal methods. IOSR J Appl Chem 2015, 8, 66-72.

34. Król, A.; Pomastowski, P.; Rafińska, K.; Railean-Plugaru, V.; Buszewski, B. Zinc oxide nanoparticles: Synthesis, antiseptic activity and toxicity mechanism. Adv. Colloid Interface Sci. 2017, 249, 37-52. [CrossRef]

35. Li, X.; He, G.; Xiao, G.; Liu, H.; Wang, M. Synthesis and morphology control of ZnO nanostructures in microemulsions. J. Colloid Interface Sci. 2009, 333, 465-473. [CrossRef]

36. Naveed Ul Haq, A.; Nadhman, A.; Ullah, I.; Mustafa, G.; Yasinzai, M.; Khan, I. Synthesis approaches of zinc oxide nanoparticles: The dilemma of ecotoxicity. J. Nanomater. 2017, 2017, 8510342. [CrossRef]

37. Dong, L.; Cui, Z.; Zhang, Z. Gas sensing properties of nano-ZnO prepared by arc plasma method. Nanostruct. Mater. 1997, 8, 815-823. [CrossRef]

38. Huang, M.H.; Wu, Y.; Feick, H.; Tran, N.; Weber, E.; Yang, P. Catalytic growth of zinc oxide nanowires by vapor transport. Adv. Mater. 2001, 13, 113-116. [CrossRef]

39. Bandeira, M.; Giovanela, M.; Roesch-Ely, M.; Devine, D.M.; da Silva Crespo, J. Green synthesis of zinc oxide nanoparticles: A review of the synthesis methodology and mechanism of formation. Sustain. Chem. Pharm. 2020, 15, 100223. [CrossRef]

40. Akhtar, M.J.; Ahamed, M.; Kumar, S.; Khan, M.M.; Ahmad, J.; Alrokayan, S.A. Zinc oxide nanoparticles selectively induce apoptosis in human cancer cells through reactive oxygen species. Int. J. Nanomed. 2012, 7, 845. 
41. Chung, I.-M.; Rahuman, A.A.; Marimuthu, S.; Kirthi, A.V.; Anbarasan, K.; Rajakumar, G. An investigation of the cytotoxicity and caspase-mediated apoptotic effect of green synthesized zinc oxide nanoparticles using Eclipta prostrata on human liver carcinoma cells. Nanomaterials 2015, 5, 1317-1330. [CrossRef] [PubMed]

42. Abbasi, B.A.; Iqbal, J.; Ahmad, R.; Zia, L.; Kanwal, S.; Mahmood, T.; Wang, C.; Chen, J.-T. Bioactivities of Geranium wallichianum leaf extracts conjugated with zinc oxide nanoparticles. Biomolecules 2020, 10, 38. [CrossRef]

43. Akintelu, S.A.; Folorunso, A.S. A review on green synthesis of zinc oxide nanoparticles using plant extracts and its biomedical applications. BioNanoScience 2020, 10, 848-863. [CrossRef]

44. Mishra, P.K.; Mishra, H.; Ekielski, A.; Talegaonkar, S.; Vaidya, B. Zinc oxide nanoparticles: A promising nanomaterial for biomedical applications. Drug Discov. Today 2017, 22, 1825-1834. [CrossRef] [PubMed]

45. Zhang, Z.-Y.; Xiong, H.-M. Photoluminescent ZnO nanoparticles and their biological applications. Materials 2015, 8, 3101-3127. [CrossRef]

46. Kim, S.; Lee, S.Y.; Cho, H.-J. Doxorubicin-wrapped zinc oxide nanoclusters for the therapy of colorectal adenocarcinoma. Nanomaterials 2017, 7, 354. [CrossRef] [PubMed]

47. Xiong, H.M. ZnO nanoparticles applied to bioimaging and drug delivery. Adv. Mater. 2013, 25, 5329-5335. [CrossRef]

48. Wiesmann, N.; Tremel, W.; Brieger, J. Zinc oxide nanoparticles for therapeutic purposes in cancer medicine. J. Mater. Chem. B 2020, 8, 4973-4989. [CrossRef] [PubMed]

49. Jayaseelan, C.; Rahuman, A.A.; Kirthi, A.V.; Marimuthu, S.; Santhoshkumar, T.; Bagavan, A.; Gaurav, K.; Karthik, L.; Rao, K.B. Novel microbial route to synthesize $\mathrm{ZnO}$ nanoparticles using Aeromonas hydrophila and their activity against pathogenic bacteria and fungi. Spectrochim. Acta Part A Mol. Biomol. Spectrosc. 2012, 90, 78-84. [CrossRef] [PubMed]

50. Baum, M.K.; Shor-Posner, G.; Campa, A. Zinc status in human immunodeficiency virus infection. J. Nutr. 2000, 130, 1421S-1423S. [CrossRef] [PubMed]

51. Hiller, J.M.; Perlmutter, A. Effect of zinc on viral-host interactions in a rainbow trout cell line, RTG-2. Water Res. 1971, 5, 703-710. [CrossRef]

52. Rasmussen, J.W.; Martinez, E.; Louka, P.; Wingett, D.G. Zinc oxide nanoparticles for selective destruction of tumor cells and potential for drug delivery applications. Expert Opin. Drug Deliv. 2010, 7, 1063-1077. [CrossRef]

53. Mirzaei, H.; Darroudi, M. Zinc oxide nanoparticles: Biological synthesis and biomedical applications. Ceram. Int. 2017, 43, 907-914. [CrossRef]

54. Newman, M.D.; Stotland, M.; Ellis, J.I. The safety of nanosized particles in titanium dioxide-and zinc oxide-based sunscreens. J. Am. Acad. Dermatol. 2009, 61, 685-692. [CrossRef]

55. Kołodziejczak-Radzimska, A.; Jesionowski, T. Zinc oxide-From synthesis to application: A review. Materials 2014, 7, $2833-2881$. [CrossRef]

56. Sahoo, S.; Maiti, M.; Ganguly, A.; Jacob George, J.; Bhowmick, A.K. Effect of zinc oxide nanoparticles as cure activator on the properties of natural rubber and nitrile rubber. J. Appl. Polym. Sci. 2007, 105, 2407-2415. [CrossRef]

57. Rajeshkumar, S.; Lakshmi, T.; Naik, P. Recent advances and biomedical applications of zinc oxide nanoparticles. In Green Synthesis, Characterization and Applications of Nanoparticles; Elsevier: Amsterdam, The Netherlands, 2019; pp. 445-457.

58. Barui, A.K.; Kotcherlakota, R.; Patra, C.R. Biomedical applications of zinc oxide nanoparticles. In Inorganic Frameworks as Smart Nanomedicines; Elsevier: Amsterdam, The Netherlands, 2018; pp. 239-278.

59. Zhang, Y.; R Nayak, T.; Hong, H.; Cai, W. Biomedical applications of zinc oxide nanomaterials. Curr. Mol. Med. 2013, 13, 1633-1645. [CrossRef] [PubMed]

60. Wang, Y.; Song, S.; Liu, J.; Liu, D.; Zhang, H. ZnO-functionalized upconverting nanotheranostic agent: Multi-modality imagingguided chemotherapy with on-demand drug release triggered by $\mathrm{pH}$. Angew. Chem. Int. Ed. 2015, 54, 536-540. [CrossRef]

61. Muhammad, F.; Guo, M.; Qi, W.; Sun, F.; Wang, A.; Guo, Y.; Zhu, G. pH-triggered controlled drug release from mesoporous silica nanoparticles via intracelluar dissolution of ZnO nanolids. J. Am. Chem. Soc. 2011, 133, 8778-8781. [CrossRef]

62. Xia, T.; Kovochich, M.; Liong, M.; Madler, L.; Gilbert, B.; Shi, H.; Yeh, J.I.; Zink, J.I.; Nel, A.E. Comparison of the mechanism of toxicity of zinc oxide and cerium oxide nanoparticles based on dissolution and oxidative stress properties. ACS Nano 2008, 2, 2121-2134. [CrossRef] [PubMed]

63. Chen, H.; Zhen, Z.; Todd, T.; Chu, P.K.; Xie, J. Nanoparticles for improving cancer diagnosis. Mater. Sci. Eng. R. Rep. 2013, 74, 35-69. [CrossRef] [PubMed]

64. Anik, Ü. Gold Nanoparticle-Based Electrochemical Biosensors for Medical Applictions. Biosens. Nanotechnol. 2014, 3, 63-80.

65. German, N.; Kausaite-Minkstimiene, A.; Ramanavicius, A.; Semashko, T.; Mikhailova, R.; Ramanaviciene, A. The use of different glucose oxidases for the development of an amperometric reagentless glucose biosensor based on gold nanoparticles covered by polypyrrole. Electrochim. Acta 2015, 169, 326-333. [CrossRef]

66. Wang, J. Electrochemical biosensors: Towards point-of-care cancer diagnostics. Biosens. Bioelectron. 2006, 21, 1887-1892. [CrossRef] [PubMed]

67. Chikkaveeraiah, B.V.; Bhirde, A.A.; Morgan, N.Y.; Eden, H.S.; Chen, X. Electrochemical immunosensors for detection of cancer protein biomarkers. ACS Nano 2012, 6, 6546-6561. [CrossRef] [PubMed]

68. Mita, Y.; Aoyagi, Y.; Yanagi, M.; Suda, T.; Suzuki, Y.; Asakura, H. The usefulness of determining des- $\gamma$-carboxy prothrombin by sensitive enzyme immunoassay in the early diagnosis of patients with hepatocellular carcinoma. Cancer: Interdiscip. Int. J. Am. Cancer Soc. 1998, 82, 1643-1648. [CrossRef] 
69. Ching, C.T.-S.; Van Hieu, N.; Cheng, T.-Y.; Fu, L.-S.; Sun, T.-P.; Liu, M.-Y.; Huang, S.-H.; Yao, Y.-D. Liver cancer detection by a simple, inexpensive and effective immunosensor with zinc oxide nanoparticles. Sensors 2015, 15, 29408-29418. [CrossRef] [PubMed]

70. Ramesh, T.; Foo, K.L.; Haarindraprasad, R.; Sam, A.J.; Solayappan, M. Gold-Hybridized Zinc oxide nanorods as Real-time Low-cost nanoBiosensors for Detection of virulent DNA signature of HPV-16 in cervical carcinoma. Sci. Rep. 2019, 9, 1-17. [CrossRef]

71. Thiagarajan, V.; Madhurantakam, S.; Sethuraman, S.; Rayappan, J.B.B.; Krishnan, U.M. Nano interfaced biosensor for detection of choline in triple negative breast cancer cells. J. Colloid Interface Sci. 2016, 462, 334-340. [CrossRef]

72. Scanlon, M.D.; Salaj-Kosla, U.; Belochapkine, S.; MacAodha, D.; Leech, D.; Ding, Y.; Magner, E. Characterization of nanoporous gold electrodes for bioelectrochemical applications. Langmuir 2012, 28, 2251-2261. [CrossRef]

73. Solanki, P.R.; Kaushik, A.; Agrawal, V.V.; Malhotra, B.D. Nanostructured metal oxide-based biosensors. NPG Asia Mater. 2011, 3, 17-24. [CrossRef]

74. Ali, M.A.; Mondal, K.; Singh, C.; Malhotra, B.D.; Sharma, A. Anti-epidermal growth factor receptor conjugated mesoporous zinc oxide nanofibers for breast cancer diagnostics. Nanoscale 2015, 7, 7234-7245. [CrossRef] [PubMed]

75. Jiang, H.; Wang, H.; Wang, X. Facile and mild preparation of fluorescent $\mathrm{ZnO}$ nanosheets and their bioimaging applications. Appl. Surf. Sci. 2011, 257, 6991-6995. [CrossRef]

76. Xiong, H.-M.; Xu, Y.; Ren, Q.-G.; Xia, Y.-Y. Stable aqueous ZnO@ polymer core-Shell nanoparticles with tunable photoluminescence and their application in cell imaging. J. Am. Chem. Soc. 2008, 130, 7522-7523. [CrossRef] [PubMed]

77. Zahin, N.; Anwar, R.; Tewari, D.; Kabir, M.T.; Sajid, A.; Mathew, B.; Uddin, M.S.; Aleya, L.; Abdel-Daim, M.M. Nanoparticles and its biomedical applications in health and diseases: Special focus on drug delivery. Environ. Sci. Pollut. Res. 2019, 27, 19151-19168. [CrossRef] [PubMed]

78. Moghimi, S.M.; Hunter, A.C.; Murray, J.C. Long-circulating and target-specific nanoparticles: Theory to practice. Pharmacol. Rev. 2001, 53, 283-318.

79. Dhivya, R.; Ranjani, J.; Bowen, P.K.; Rajendhran, J.; Mayandi, J.; Annaraj, J. Biocompatible curcumin loaded PMMA-PEG/ZnO nanocomposite induce apoptosis and cytotoxicity in human gastric cancer cells. Mater. Sci. Eng. C 2017, 80, 59-68. [CrossRef] [PubMed]

80. George, D.; Maheswari, P.U.; Begum, K.M.S. Synergic formulation of onion peel quercetin loaded chitosan-cellulose hydrogel with green zinc oxide nanoparticles towards controlled release, biocompatibility, antimicrobial and anticancer activity. Int. J. Biol. Macromol. 2019, 132, 784-794. [CrossRef]

81. Huang, X.; Zheng, X.; Xu, Z.; Yi, C. ZnO-based nanocarriers for drug delivery application: From passive to smart strategies. Int. J. Pharm. 2017, 534, 190-194. [CrossRef]

82. Shetti, N.P.; Malode, S.J.; Nayak, D.S.; Bagihalli, G.B.; Kalanur, S.S.; Malladi, R.S.; Reddy, C.V.; Aminabhavi, T.M.; Reddy, K.R. Fabrication of $\mathrm{ZnO}$ nanoparticles modified sensor for electrochemical oxidation of methdilazine. Appl. Surf. Sci. 2019, $496,143656$. [CrossRef]

83. Zheng, J.; Jiang, Z.-Y.; Kuang, Q.; Xie, Z.-X.; Huang, R.-B.; Zheng, L.-S. Shape-controlled fabrication of porous ZnO architectures and their photocatalytic properties. J. Solid State Chem. 2009, 182, 115-121. [CrossRef]

84. Vimala, K.; Sundarraj, S.; Paulpandi, M.; Vengatesan, S.; Kannan, S. Green synthesized doxorubicin loaded zinc oxide nanoparticles regulates the Bax and Bcl-2 expression in breast and colon carcinoma. Process Biochem. 2014, 49, 160-172. [CrossRef]

85. Byrne, J.D.; Betancourt, T.; Brannon-Peppas, L. Active targeting schemes for nanoparticle systems in cancer therapeutics. Adv. Drug Deliv. Rev. 2008, 60, 1615-1626. [CrossRef]

86. Varki, A. Glycan-based interactions involving vertebrate sialic-acid-recognizing proteins. Nature 2007, 446, 1023-1029. [CrossRef]

87. Aung, T.N.; Qu, Z.; Kortschak, R.D.; Adelson, D.L. Understanding the effectiveness of natural compound mixtures in cancer through their molecular mode of action. Int. J. Mol. Sci. 2017, 18, 656. [CrossRef]

88. Thakore, P.; Mani, R.K.; Kavitha, S.J. A brief review of plants having anti-cancer property. Int J Pharm Res Dev 2012, 3, 129-136.

89. Tariq, A.; Sadia, S.; Pan, K.; Ullah, I.; Mussarat, S.; Sun, F.; Abiodun, O.O.; Batbaatar, A.; Li, Z.; Song, D. A systematic review on ethnomedicines of anti-cancer plants. Phytother. Res. 2017, 31, 202-264. [CrossRef]

90. Sundraraman, G.; Jayakumari, L. Meticulous taxifolin releasing performance by the zinc oxide nanoparticles: As a short road to drug delivery system for cancer therapeutics. J. Clust. Sci. 2020, 31, 241-255. [CrossRef]

91. George, D.; Maheswari, P.U.; Begum, K.M.S. Chitosan-cellulose hydrogel conjugated with L-histidine and zinc oxide nanoparticles for sustained drug delivery: Kinetics and in-vitro biological studies. Carbohydr. Polym. 2020, 236, 116101. [CrossRef] [PubMed]

92. Sawant, V.; Bamane, S. PEG-beta-cyclodextrin functionalized zinc oxide nanoparticles show cell imaging with high drug payload and sustained pH responsive delivery of curcumin in to MCF-7 cells. J. Drug Deliv. Sci. Technol. 2018, 43, 397-408. [CrossRef]

93. Sharma, H.; Kumar, K.; Choudhary, C.; Mishra, P.K.; Vaidya, B. Development and characterization of metal oxide nanoparticles for the delivery of anticancer drug. Artif. Cells Nanomed. Biotechnol. 2016, 44, 672-679. [CrossRef] [PubMed]

94. Wang, H.; Wingett, D.; Engelhard, M.H.; Feris, K.; Reddy, K.; Turner, P.; Layne, J.; Hanley, C.; Bell, J.; Tenne, D. Fluorescent dye encapsulated $\mathrm{ZnO}$ particles with cell-specific toxicity for potential use in biomedical applications. J. Mater. Sci. Mater. Med. 2009, 20, 11-22. [CrossRef] [PubMed]

95. Vimala, K.; Shanthi, K.; Sundarraj, S.; Kannan, S. Synergistic effect of chemo-photothermal for breast cancer therapy using folic acid (FA) modified zinc oxide nanosheet. J. Colloid Interface Sci. 2017, 488, 92-108. [CrossRef] [PubMed] 
96. Yuan, Q.; Hein, S.; Misra, R. New generation of chitosan-encapsulated ZnO quantum dots loaded with drug: Synthesis, characterization and in vitro drug delivery response. Acta Biomater. 2010, 6, 2732-2739. [CrossRef] [PubMed]

97. Goethals, E.C.; Elbaz, A.; Lopata, A.L.; Bhargava, S.K.; Bansal, V. Decoupling the effects of the size, wall thickness, and porosity of curcumin-loaded chitosan nanocapsules on their anticancer efficacy: Size is the winner. Langmuir 2013, 29, 658-666. [CrossRef] [PubMed]

98. Yuan, Q.; Cayre, O.J.; Fujii, S.; Armes, S.P.; Williams, R.A.; Biggs, S. Responsive Core—Shell Latex Particles as Colloidosome Microcapsule Membranes. Langmuir 2010, 26, 18408-18414. [CrossRef] [PubMed]

99. Puvvada, N.; Rajput, S.; Kumar, B.P.; Sarkar, S.; Konar, S.; Brunt, K.R.; Rao, R.R.; Mazumdar, A.; Das, S.K.; Basu, R. Novel $\mathrm{ZnO}$ hollow-nanocarriers containing paclitaxel targeting folate-receptors in a malignant $\mathrm{pH}$-microenvironment for effective monitoring and promoting breast tumor regression. Sci. Rep. 2015, 5, 1-15. [CrossRef] [PubMed]

100. Kundu, D.; Hazra, C.; Chatterjee, A.; Chaudhari, A.; Mishra, S. Extracellular biosynthesis of zinc oxide nanoparticles using Rhodococcus pyridinivorans NT2: Multifunctional textile finishing, biosafety evaluation and in vitro drug delivery in colon carcinoma. J. Photochem. Photobiol. B: Biol. 2014, 140, 194-204. [CrossRef] [PubMed]

101. Heffeter, P.; Jungwirth, U.; Jakupec, M.; Hartinger, C.; Galanski, M.; Elbling, L.; Micksche, M.; Keppler, B.; Berger, W. Resistance against novel anticancer metal compounds: Differences and similarities. Drug Resist. Updates 2008, 11, 1-16. [CrossRef]

102. Sava, G.; Zorzet, S.; Giraldi, T.; Mestroni, G.; Zassinovich, G. Antineoplastic activity and toxicity of an organometallic complex of ruthenium (II) in comparison with cis-PDD in mice bearing solid malignant neoplasms. Eur. J. Cancer Clin. Oncol. 1984, 20, 841-847. [CrossRef]

103. Sava, G.; Bergamo, A. Ruthenium-based compounds and tumour growth control. Int. J. Oncol. 2000, 17, 353-418. [CrossRef]

104. Zhou, W. Cholic Acid-Functionalized Mesoporous Silica Nanoparticles Loaded with Ruthenium Pro-Drug Delivery to Cervical Cancer Therapy. J. Inorg. Organomet. Polym. Mater. 2021, 31, 311-318. [CrossRef]

105. Yun, Y.H.; Goetz, D.J.; Yellen, P.; Chen, W. Hyaluronan microspheres for sustained gene delivery and site-specific targeting. Biomaterials 2004, 25, 147-157. [CrossRef]

106. Toole, B.P.; Wight, T.N.; Tammi, M.I. Hyaluronan-cell interactions in cancer and vascular disease. J. Biol. Chem. 2002, 277, 4593-4596. [CrossRef]

107. He, M.; Zhao, Z.; Yin, L.; Tang, C.; Yin, C. Hyaluronic acid coated poly (butyl cyanoacrylate) nanoparticles as anticancer drug carriers. Int. J. Pharm. 2009, 373, 165-173. [CrossRef]

108. Wang, J.; Kaskel, S. KOH activation of carbon-based materials for energy storage. J. Mater. Chem. 2012, 22, 23710-23725. [CrossRef]

109. Singh, N.B.; Agarwal, S. Nanocomposites: An overview. Emerg. Mater. Res. 2016, 5, 5-43. [CrossRef]

110. Baskar, G.; Chandhuru, J.; Fahad, K.S.; Praveen, A.; Chamundeeswari, M.; Muthukumar, T. Anticancer activity of fungal L-asparaginase conjugated with zinc oxide nanoparticles. J. Mater. Sci. Mater. Med. 2015, 26, 43. [CrossRef] [PubMed]

111. Sathishkumar, P.; Li, Z.; Govindan, R.; Jayakumar, R.; Wang, C.; Gu, F.L. Zinc oxide-quercetin nanocomposite as a smart nano-drug delivery system: Molecular-level interaction studies. Appl. Surf. Sci. 2021, 536, 147741. [CrossRef]

112. Namvar, F.; Azizi, S.; Rahman, H.S.; Mohamad, R.; Rasedee, A.; Soltani, M.; Rahim, R.A. Green synthesis, characterization, and anticancer activity of hyaluronan/zinc oxide nanocomposite. Oncotargets Ther. 2016, 9, 4549.

113. Hauner, K.; Maisch, P.; Retz, M. Side effects of chemotherapy. Urol. Ausg. A 2017, 56, 472-479. [CrossRef]

114. Mohan, G.; TP, A.H.; Jijo, A.; KM, S.D.; Narayanasamy, A.; Vellingiri, B. Recent advances in radiotherapy and its associated side effects in cancer-a review. J. Basic Appl. Zool. 2019, 80, 1-10. [CrossRef]

115. Wahab, R.; Siddiqui, M.A.; Saquib, Q.; Dwivedi, S.; Ahmad, J.; Musarrat, J.; Al-Khedhairy, A.A.; Shin, H.-S. ZnO nanoparticles induced oxidative stress and apoptosis in HepG2 and MCF-7 cancer cells and their antibacterial activity. Colloids Surf. B Biointerfaces 2014, 117, 267-276. [CrossRef]

116. Selvakumari, D.; Deepa, R.; Mahalakshmi, V.; Subhashini, P.; Lakshminarayan, N. Anti cancer activity of ZnO nanoparticles on MCF7 (breast cancer cell) and A549 (lung cancer cell). ARPN J. Eng. Appl. Sci 2015, 10, 5418-5421.

117. Wang, Y.; Zhang, Y.; Guo, Y.; Lu, J.; Veeraraghavan, V.P.; Mohan, S.K.; Wang, C.; Yu, X. Synthesis of Zinc oxide nanoparticles from Marsdenia tenacissima inhibits the cell proliferation and induces apoptosis in laryngeal cancer cells (Hep-2). J. Photochem. Photobiol. B Biol. 2019, 201, 111624. [CrossRef]

118. Hussain, A.; Oves, M.; Alajmi, M.F.; Hussain, I.; Amir, S.; Ahmed, J.; Rehman, M.T.; El-Seedi, H.R.; Ali, I. Biogenesis of ZnO nanoparticles using Pandanus odorifer leaf extract: Anticancer and antimicrobial activities. RSC Adv. 2019, 9, 15357-15369. [CrossRef]

119. Boroumand Moghaddam, A.; Moniri, M.; Azizi, S.; Abdul Rahim, R.; Bin Ariff, A.; Navaderi, M.; Mohamad, R. Eco-friendly formulated zinc oxide nanoparticles: Induction of cell cycle arrest and apoptosis in the MCF-7 cancer cell line. Genes 2017, 8, 281. [CrossRef] [PubMed]

120. Wahab, R.; Dwivedi, S.; Umar, A.; Singh, S.; Hwang, I.; Shin, H.-S.; Musarrat, J.; Al-Khedhairy, A.A.; Kim, Y.-S. ZnO nanoparticles induce oxidative stress in Cloudman S91 melanoma cancer cells. J. Biomed. Nanotechnol. 2013, 9, 441-449. [CrossRef] [PubMed]

121. Siegel, R.L.; Miller, K.D.; Jemal, A. Cancer statistics, 2019. Cancer J. Clin. 2019, 69, 7-34. [CrossRef] [PubMed]

122. Center, M.M.; Jemal, A. International trends in liver cancer incidence rates. Cancer Epidemiol. Prev. Biomark. 2011, 20, 2362-2368. [CrossRef]

123. El-Serag, H.B.; Marrero, J.A.; Rudolph, L.; Reddy, K.R. Diagnosis and treatment of hepatocellular carcinoma. Gastroenterology 2008, 134, 1752-1763. [CrossRef] [PubMed] 
124. Anwanwan, D.; Singh, S.K.; Singh, S.; Saikam, V.; Singh, R. Challenges in liver cancer and possible treatment approaches. Biochim. Biophys. Acta Rev. Cancer 2020, 1873, 188314. [CrossRef]

125. Sharma, V.; Anderson, D.; Dhawan, A. Zinc oxide nanoparticles induce oxidative DNA damage and ROS-triggered mitochondria mediated apoptosis in human liver cells (HepG2). Apoptosis 2012, 17, 852-870. [CrossRef]

126. Basu, A.; Haldar, S. The relationship between BcI2, Bax and p53: Consequences for cell cycle progression and cell death. Mol. Hum. Reprod. 1998, 4, 1099-1109. [CrossRef]

127. Han, E.-S.; Muller, F.L.; Pérez, V.I.; Qi, W.; Liang, H.; Xi, L.; Fu, C.; Doyle, E.; Hickey, M.; Cornell, J. The in vivo gene expression signature of oxidative stress. Physiol. Genom. 2008, 34, 112-126. [CrossRef]

128. Sullivan, K.D.; Gallant-Behm, C.L.; Henry, R.E.; Fraikin, J.-L.; Espinosa, J.M. The p53 circuit board. Biochim. Biophys. Acta Rev. Cancer 2012, 1825, 229-244. [CrossRef]

129. Choi, M.; Shi, J.; Jung, S.H.; Chen, X.; Cho, K.-H. Attractor landscape analysis reveals feedback loops in the p53 network that control the cellular response to DNA damage. Sci. Signal. 2012, 5, ra83. [CrossRef]

130. Thomas, A.; El Rouby, S.; Reed, J.C.; Krajewski, S.; Silber, R.; Potmesil, M.; Newcomb, E.W. Drug-induced apoptosis in B-cell chronic lymphocytic leukemia: Relationship between p53 gene mutation and bcl-2/bax proteins in drug resistance. Oncogene 1996, 12, 1055-1062. [PubMed]

131. Toshiyuki, M.; Reed, J.C. Tumor suppressor p53 is a direct transcriptional activator of the human bax gene. Cell 1995, 80, 293-299. [CrossRef]

132. McCurrach, M.E.; Connor, T.M.; Knudson, C.M.; Korsmeyer, S.J.; Lowe, S.W. bax-deficiency promotes drug resistance and oncogenic transformation by attenuating p53-dependent apoptosis. Proc. Natl. Acad. Sci. USA 1997, 94, 2345-2349. [CrossRef] [PubMed]

133. Yin, C.; Knudson, C.M.; Korsmeyer, S.J.; Van Dyke, T. Bax suppresses tumorigenesis and stimulates apoptosis in vivo. Nature 1997, 385, 637-640. [CrossRef]

134. Rahimi Kalateh Shah Mohammad, G.; Seyedi, S.M.R.; Karimi, E.; Homayouni-Tabrizi, M. The cytotoxic properties of zinc oxide nanoparticles on the rat liver and spleen, and its anticancer impacts on human liver cancer cell lines. J. Biochem. Mol. Toxicol. 2019, 33, e22324. [CrossRef]

135. Sonnemann, J.; Gänge, J.; Pilz, S.; Stötzer, C.; Ohlinger, R.; Belau, A.; Lorenz, G.; Beck, J.F. Comparative evaluation of the treatment efficacy of suberoylanilide hydroxamic acid (SAHA) and paclitaxel in ovarian cancer cell lines and primary ovarian cancer cells from patients. BMC Cancer 2006, 6, 183. [CrossRef]

136. Yang, R.; Wu, R.; Mei, J.; Hu, F.; Lei, C. Zinc oxide nanoparticles promotes liver cancer cell apoptosis through inducing autophagy and promoting p53. Eur. Rev. Med. Pharmacol. Sci. 2021, 25, 1557-1563.

137. Iravani, S.; Korbekandi, H.; Mirmohammadi, S.V.; Zolfaghari, B. Synthesis of silver nanoparticles: Chemical, physical and biological methods. Res. Pharm. Sci. 2014, 9, 385.

138. Duran, N.; Seabra, A.B. Biogenic synthesized Ag/Au nanoparticles: Production, characterization, and applications. Curr. Nanosci. 2018, 14, 82-94. [CrossRef]

139. Seabra, A.B.; Duran, N. Nanotoxicology of metal oxide nanoparticles. Metals 2015, 5, 934-975. [CrossRef]

140. Singh, P.; Kim, Y.-J.; Zhang, D.; Yang, D.-C. Biological synthesis of nanoparticles from plants and microorganisms. Trends Biotechnol. 2016, 34, 588-599. [CrossRef]

141. Sanaeimehr, Z.; Javadi, I.; Namvar, F. Antiangiogenic and antiapoptotic effects of green-synthesized zinc oxide nanoparticles using Sargassum muticum algae extraction. Cancer Nanotechnol. 2018, 9, 1-16. [CrossRef] [PubMed]

142. Decarli, A.; Calza, S.; Masala, G.; Specchia, C.; Palli, D.; Gail, M.H. Gail model for prediction of absolute risk of invasive breast cancer: Independent evaluation in the Florence-European prospective investigation into Cancer and Nutrition Cohort. J. Natl. Cancer Inst. 2006, 98, 1686-1693. [CrossRef] [PubMed]

143. Thun, M.J.; Carter, B.D.; Feskanich, D.; Freedman, N.D.; Prentice, R.; Lopez, A.D.; Hartge, P.; Gapstur, S.M. 50-year trends in smoking-related mortality in the United States. N. Engl. J. Med. 2013, 368, 351-364. [CrossRef] [PubMed]

144. Youlden, D.R.; Cramb, S.M.; Baade, P.D. The International Epidemiology of Lung Cancer: Geographical distribution and secular trends. J. Thorac. Oncol. 2008, 3, 819-831. [CrossRef] [PubMed]

145. Jemal, A. Centre MM, Desantis C., Ward EM. Global patterns of cancer incidence and mortality rates and trends. Cancer Epidemiol. Biomark. Prev. 2010, 19, 1893-1907. [CrossRef] [PubMed]

146. Downing-Perrault, A. Polymer Nanocomposites are the Future; University of Wisconsin-Stout: Menomonie, WI, USA, 2005.

147. Lakshminarayanan, R.; Loh, X.J.; Gayathri, S.; Sindhu, S.; Banerjee, Y.; Kini, R.M.; Valiyaveettil, S. Formation of transient amorphous calcium carbonate precursor in quail eggshell mineralization: An in vitro study. Biomacromolecules 2006, 7, 3202-3209. [CrossRef] [PubMed]

148. Lakshminarayanan, R.; Chi-Jin, E.O.; Loh, X.J.; Kini, R.M.; Valiyaveettil, S. Purification and Characterization of a Vaterite-Inducing Peptide, Pelovaterin, from the Eggshells of Pelodiscus s Inensis (Chinese Soft-Shelled Turtle). Biomacromolecules 2005, 6, $1429-1437$. [CrossRef] [PubMed]

149. Hira, I.; Kumar, A.; Kumari, R.; Saini, A.K.; Saini, R.V. Pectin-guar gum-zinc oxide nanocomposite enhances human lymphocytes cytotoxicity towards lung and breast carcinomas. Mater. Sci. Eng. C 2018, 90, 494-503. [CrossRef]

150. Zou, L.; Wang, H.; He, B.; Zeng, L.; Tan, T.; Cao, H.; He, X.; Zhang, Z.; Guo, S.; Li, Y. Current approaches of photothermal therapy in treating cancer metastasis with nanotherapeutics. Theranostics 2016, 6, 762. [CrossRef] 
151. Kim, S.; Lee, S.Y.; Cho, H.-J. Berberine and zinc oxide-based nanoparticles for the chemo-photothermal therapy of lung adenocarcinoma. Biochem. Biophys. Res. Commun. 2018, 501, 765-770. [CrossRef]

152. Rajeshkumar, S.; Kumar, S.V.; Ramaiah, A.; Agarwal, H.; Lakshmi, T.; Roopan, S.M. Biosynthesis of zinc oxide nanoparticles usingMangifera indica leaves and evaluation of their antioxidant and cytotoxic properties in lung cancer (A549) cells. Enzym. Microb. Technol. 2018, 117, 91-95. [CrossRef]

153. Umamaheswari, A.; Prabu, S.L.; John, S.A.; Puratchikody, A. Green synthesis of zinc oxide nanoparticles using leaf extracts of Raphanus sativus var. Longipinnatus and evaluation of their anticancer property in A549 cell lines. Biotechnol. Rep. 2021, 29, e00595. [CrossRef]

154. Elkady, A.I.; Abuzinadah, O.A.; Baeshen, N.A.; Rahmy, T.R. Differential control of growth, apoptotic activity, and gene expression in human breast cancer cells by extracts derived from medicinal herbs Zingiber officinale. J. Biomed. Biotechnol. 2012, $2012,614356$. [CrossRef]

155. Olsson, M.; Zhivotovsky, B. Caspases and cancer. Cell Death Differ. 2011, 18, 1441-1449. [CrossRef]

156. Ng, K.W.; Khoo, S.P.; Heng, B.C.; Setyawati, M.I.; Tan, E.C.; Zhao, X.; Xiong, S.; Fang, W.; Leong, D.T.; Loo, J.S. The role of the tumor suppressor p53 pathway in the cellular DNA damage response to zinc oxide nanoparticles. Biomaterials 2011, 32, 8218-8225. [CrossRef]

157. Huber, K.L.; Hardy, J.A. Mechanism of zinc-mediated inhibition of caspase-9. Protein Sci. 2012, 21, 1056-1065. [CrossRef]

158. Kadhem, H.A.; Ibraheem, S.A.; Jabir, M.S.; Kadhim, A.A. Zainab Jihad Taqi, and Mihailescu Dan Florin, Zinc Oxide Nanoparticles Induce Apoptosis in Human Breast Cancer Cells via Caspase-8 and P53 Pathway. Nano Biomed. Eng. 2019, 11, 35-43. [CrossRef]

159. Shamasi, Z.; Es-haghi, A.; Taghavizadeh Yazdi, M.E.; Amiri, M.S.; Homayouni-Tabrizi, M. Role of Rubia tinctorum in the synthesis of zinc oxide nanoparticles and apoptosis induction in breast cancer cell line. Nanomed. J. 2021, 8, 65-72.

160. Mahdizadeh, R.; Homayouni-Tabrizi, M.; Neamati, A.; Seyedi, S.M.R.; Tavakkol Afshari, H.S. Green synthesized-zinc oxide nanoparticles, the strong apoptosis inducer as an exclusive antitumor agent in murine breast tumor model and human breast cancer cell lines (MCF7). J. Cell. Biochem. 2019, 120, 17984-17993. [CrossRef] [PubMed]

161. Boskabadi, S.H.; Balanezhad, S.Z.; Neamati, A.; Tabrizi, M.H. The green-synthesized zinc oxide nanoparticle as a novel natural apoptosis inducer in human breast (MCF7 and MDA-MB231) and colon (HT-29) cancer cells. Inorg. Nano-Met. Chem. 2020, 51, 733-743. [CrossRef]

162. Shandiz, S.A.S.; Sharifian, F.; Behboodi, S.; Ghodratpour, F.; Baghbani-Arani, F. Evaluation of Metastasis Suppressor Genes Expression and In Vitro Anti-Cancer Effects of Zinc Oxide Nanoparticles in Human Breast Cancer Cell Lines MCF-7 and T47D. Avicenna J. Med Biotechnol. 2021, 13, 9.

163. Vigneshwaran, N.; Kumar, S.; Kathe, A.; Varadarajan, P.; Prasad, V. Functional finishing of cotton fabrics using zinc oxide-soluble starch nanocomposites. Nanotechnology 2006, 17, 5087. [CrossRef]

164. Chauhan, R.; Kumar, A.; Chaudhary, R.P. Structures and optical properties of $\mathrm{Zn} 1-\times \mathrm{Ni} \times$ O nanoparticles by coprecipitation method. Res. Chem. Intermed. 2012, 38, 1483-1493. [CrossRef]

165. Bangroo, A.; Malhotra, A.; Sharma, U.; Jain, A.; Kaur, A. Biological Fabrication and Characterization of Zinc Oxide Nanoparticles Using Gymnema Sylvestre Potentially Produces Toxicity in Breast Cancer Cells-MCF-7. J. Inorg. Organomet. Polym. Mater. 2021, in press. [CrossRef]

166. Malaikozhundan, B.; Vaseeharan, B.; Vijayakumar, S.; Pandiselvi, K.; Kalanjiam, M.A.R.; Murugan, K.; Benelli, G. Biological therapeutics of Pongamia pinnata coated zinc oxide nanoparticles against clinically important pathogenic bacteria, fungi and MCF-7 breast cancer cells. Microb. Pathog. 2017, 104, 268-277. [CrossRef]

167. Prasad, K.S.; Prasad, S.K.; Veerapur, R.; Lamraoui, G.; Prasad, A.; Prasad, M.; Singh, S.K.; Marraiki, N.; Syed, A.; Shivamallu, C. Antitumor Potential of Green Synthesized ZnONPs Using Root Extract of Withania somnifera against Human Breast Cancer Cell Line. Separations 2021, 8, 8. [CrossRef]

168. Loganathan, S.; Shivakumar, M.S.; Karthi, S.; Nathan, S.S.; Selvam, K. Metal oxide nanoparticle synthesis (ZnO-NPs) of Knoxia sumatrensis (Retz.) DC. Aqueous leaf extract and It's evaluation of their antioxidant, anti-proliferative and larvicidal activities. Toxicol. Rep. 2021, 8, 64-72. [CrossRef] [PubMed]

169. Kavithaa, K.; Paulpandi, M.; Ponraj, T.; Murugan, K.; Sumathi, S. Induction of intrinsic apoptotic pathway in human breast cancer (MCF-7) cells through facile biosynthesized zinc oxide nanorods. Karbala Int. J. Mod. Sci. 2016, 2, 46-55. [CrossRef]

170. Ali, S.; Sudha, K.G.; Karunakaran, G.; Kowsalya, M.; Kolesnikov, E.; Rajeshkumar, M.P. Green synthesis of stable antioxidant, anticancer and photocatalytic activity of zinc oxide nanorods from Leea asiatica leaf. J. Biotechnol. 2021, 329, 65-79. [CrossRef]

171. Umar, H.; Kavaz, D.; Rizaner, N. Biosynthesis of zinc oxide nanoparticles using Albizia lebbeck stem bark, and evaluation of its antimicrobial, antioxidant, and cytotoxic activities on human breast cancer cell lines. Int. J. Nanomed. 2019, 14, 87. [CrossRef]

172. D'Souza, J.N.; Prabhu, A.; Nagaraja, G.; Navada, M.; Kouser, S.; Manasa, D. Unravelling the human triple negative breast cancer suppressive activity of biocompatible zinc oxide nanostructures influenced by Vateria indica (L.) fruit phytochemicals. Mater. Sci. Eng. C 2021, 122, 111887. [CrossRef]

173. Farag, M.A.; El-Ahmady, S.H.; Elian, F.S.; Wessjohann, L.A. Metabolomics driven analysis of artichoke leaf and its commercial products via UHPLC-q-TOF-MS and chemometrics. Phytochemistry 2013, 95, 177-187. [CrossRef]

174. Sadhukhan, P.; Kundu, M.; Chatterjee, S.; Ghosh, N.; Manna, P.; Das, J.; Sil, P.C. Targeted delivery of quercetin via pH-responsive zinc oxide nanoparticles for breast cancer therapy. Mater. Sci. Eng. C 2019, 100, 129-140. [CrossRef] 
175. Rajapriya, M.; Sharmili, S.A.; Baskar, R.; Balaji, R.; Alharbi, N.S.; Kadaikunnan, S.; Khaled, J.M.; Alanzi, K.F.; Vaseeharan, B. Synthesis and characterization of zinc oxide nanoparticles using Cynara scolymus leaves: Enhanced hemolytic, antimicrobial, antiproliferative, and photocatalytic activity. J. Clust. Sci. 2020, 31, 791-801. [CrossRef]

176. Mohanty, S.; Saha, S.; Hossain, D.M.S.; Adhikary, A.; Mukherjee, S.; Manna, A.; Chakraborty, S.; Mazumdar, M.; Ray, P.; Das, K. ROS-PIAS $\gamma$ cross talk channelizes ATM signaling from resistance to apoptosis during chemosensitization of resistant tumors. Cell Death Dis. 2014, 5, e1021. [CrossRef]

177. Le Bras, M.; Clement, M.; Pervaiz, S.; Brenner, C. Reactive oxygen species and the mitochondrial signaling pathway of cell death. Histol. Histopathol. 2005, 20, 15.

178. Villeneuve, C.; Guilbeau-Frugier, C.; Sicard, P.; Lairez, O.; Ordener, C.; Duparc, T.; De Paulis, D.; Couderc, B.; Spreux-Varoquaux, O.; Tortosa, F. p53-PGC-1 $\alpha$ pathway mediates oxidative mitochondrial damage and cardiomyocyte necrosis induced by monoamine oxidase-A upregulation: Role in chronic left ventricular dysfunction in mice. Antioxid. Redox Signal. 2013, 18, 5-18. [CrossRef]

179. Chakraborty, S.; Mazumdar, M.; Mukherjee, S.; Bhattacharjee, P.; Adhikary, A.; Manna, A.; Chakraborty, S.; Khan, P.; Sen, A.; Das, T. Restoration of p53/miR-34a regulatory axis decreases survival advantage and ensures Bax-dependent apoptosis of non-small cell lung carcinoma cells. FEBS Lett. 2014, 588, 549-559. [CrossRef]

180. Chakraborti, S.; Chakraborty, S.; Saha, S.; Manna, A.; Banerjee, S.; Adhikary, A.; Sarwar, S.; Hazra, T.K.; Das, T.; Chakrabarti, P. PEG-functionalized zinc oxide nanoparticles induce apoptosis in breast cancer cells through reactive oxygen species-dependent impairment of DNA damage repair enzyme NEIL2. Free Radic. Biol. Med. 2017, 103, 35-47. [CrossRef]

181. Vijayakumar, T.S.; Mahboob, S.; Bupesh, G.; Vasanth, S.; Al-Ghanim, K.A.; Al-Misned, F.; Govindarajan, M. Facile synthesis and biophysical characterization of egg albumen-wrapped zinc oxide nanoparticles: A potential drug delivery vehicles for anticancer therapy. J. Drug Deliv. Sci. Technol. 2020, 60, 102015. [CrossRef]

182. Moore, D.D.; Luu, H.H. Osteosarcoma. Orthop. Oncol. 2014, 65-92.

183. Meyers, P.A.; Gorlick, R. Osteosarcoma. Pediatric Clin. N. Am. 1997, 44, 973-989. [CrossRef]

184. Miao, J.; Wu, S.; Peng, Z.; Tania, M.; Zhang, C. MicroRNAs in osteosarcoma: Diagnostic and therapeutic aspects. Tumor Biol. 2013, 34, 2093-2098. [CrossRef]

185. Kim, S.H.; Yook, T.H.; Kim, J.U. Rehmanniae radix, an effective treatment for patients with various inflammatory and metabolic diseases: Results from a review of Korean publications. J. Pharmacopunct. 2017, 20, 81.

186. Cheng, J.; Wang, X.; Qiu, L.; Li, Y.; Marraiki, N.; Elgorban, A.M.; Xue, L. Green synthesized zinc oxide nanoparticles regulates the apoptotic expression in bone cancer cells MG-63 cells. J. Photochem. Photobiol. B Biol. 2020, 202, 111644. [CrossRef]

187. Hassanshahian, M.; Saadatfar, A.; Masoumipour, F. Formulation and characterization of nanoemulsion from Alhagi maurorum essential oil and study of its antimicrobial, antibiofilm, and plasmid curing activity against antibiotic-resistant pathogenic bacteria. J. Environ. Health Sci. Eng. 2020, 18, 1015-1027. [CrossRef]

188. Atta, A.H.; Mouneir, S.M. Antidiarrhoeal activity of some Egyptian medicinal plant extracts. J. Ethnopharmacol. 2004, 92, 303-309. [CrossRef]

189. Almeida, R.; Navarro, D.; Barbosa-Filho, J. Plants with central analgesic activity. Phytomedicine 2001, 8, 310-322. [CrossRef]

190. Chinnathambi, A.; Alahmadi, T.A. Zinc nanoparticles green-synthesized by Alhagi maurorum leaf aqueous extract: Chemical characterization and cytotoxicity, antioxidant, and anti-osteosarcoma effects. Arab. J. Chem. 2021, 14, 103083. [CrossRef]

191. Labianca, R.; Beretta, G.D.; Kildani, B.; Milesi, L.; Merlin, F.; Mosconi, S.; Pessi, M.A.; Prochilo, T.; Quadri, A.; Gatta, G. Colon cancer. Crit. Rev. Oncol. Hematol. 2010, 74, 106-133. [CrossRef]

192. Ries, L.; Melbert, D.; Krapcho, M.; Stinchcomb, D.; Howlader, N.; Horner, M.; Mariotto, A.; Miller, B.; Feuer, E.; Altekruse, S. SEER Cancer Statistics Review, 1975-2005; US National Institutes of Health, National Cancer Institute: Bethesda, MD, USA, 2008.

193. Selim, Y.A.; Azb, M.A.; Ragab, I.; Abd El-Azim, M.H. Green synthesis of zinc oxide nanoparticles using aqueous extract of Deverra tortuosa and their cytotoxic activities. Sci. Rep. 2020, 10, 3445. [CrossRef]

194. Ahmed, Z.; Wassel, G.; Abdel-Moneim, F. A preliminary phytochemical investigation of Pituranthos tortuosus (Desf.) Benth and Hook. J. Pharm. Sci. UAR 1969, 10, 31-36.

195. Krifa, M.; Gharad, T.; Haouala, R. Biological activities of essential oil, aqueous and organic extracts of Pituranthos tortuosus (Coss.) Maire. Sci. Hortic. 2011, 128, 61-67. [CrossRef]

196. El-Belely, E.F.; Farag, M.; Said, H.A.; Amin, A.S.; Azab, E.; Gobouri, A.A.; Fouda, A. Green Synthesis of Zinc Oxide Nanoparticles (ZnO-NPs) Using Arthrospira platensis (Class: Cyanophyceae) and Evaluation of their Biomedical Activities. Nanomaterials 2021, 11, 95. [CrossRef]

197. Dulta, K.; A ğçeli, G.K.; Chauhan, P.; Jasrotia, R.; Chauhan, P. A novel approach of synthesis zinc oxide nanoparticles by bergenia ciliata rhizome extract: Antibacterial and anticancer potential. J. Inorg. Organomet. Polym. Mater. 2021, 31, 180-190. [CrossRef]

198. Sarsour, E.H.; Kumar, M.G.; Chaudhuri, L.; Kalen, A.L.; Goswami, P.C. Redox control of the cell cycle in health and disease. Antioxid. Redox Signal. 2009, 11, 2985-3011. [CrossRef]

199. Landsiedel, R.; Ma-Hock, L.; Kroll, A.; Hahn, D.; Schnekenburger, J.; Wiench, K.; Wohlleben, W. Testing metal-oxide nanomaterials for human safety. Adv. Mater. 2010, 22, 2601-2627. [CrossRef]

200. Song, Y.; Guan, R.; Lyu, F.; Kang, T.; Wu, Y.; Chen, X. In vitro cytotoxicity of silver nanoparticles and zinc oxide nanoparticles to human epithelial colorectal adenocarcinoma (Caco-2) cells. Mutat. Res. Fundam. Mol. Mech. Mutagenes. 2014, 769, 113-118. [CrossRef] 
201. Ahlam, A.A.; Shaniba, V.; Jayasree, P.; Kumar, P.M. Spondias pinnata (Lf) Kurz Leaf Extract Derived Zinc Oxide Nanoparticles Induce Dual Modes of Apoptotic-Necrotic Death in HCT 116 and K562 Cells. Biol. Trace Elem. Res. 2021, 199, $1778-1801$. [CrossRef]

202. Abbasi, B.H.; Shah, M.; Hashmi, S.S.; Nazir, M.; Naz, S.; Ahmad, W.; Khan, I.U.; Hano, C. Green Bio-Assisted Synthesis, Characterization and Biological Evaluation of Biocompatible ZnO NPs Synthesized from Different Tissues of Milk Thistle (Silybum marianum). Nanomaterials 2019, 9, 1171. [CrossRef]

203. Bray, F.; Ferlay, J.; Soerjomataram, I.; Siegel, R.L.; Torre, L.A.; Jemal, A. Global cancer statistics 2018: GLOBOCAN estimates of incidence and mortality worldwide for 36 cancers in 185 countries. CA Cancer J. Clin. 2018, 68, 394-424. [CrossRef]

204. Cohen, P.A.; Jhingran, A.; Oaknin, A.; Denny, L. Cervical cancer. Lancet 2019, 393, 169-182. [CrossRef]

205. Hanley, C.; Layne, J.; Punnoose, A.; Reddy, K.; Coombs, I.; Coombs, A.; Feris, K.; Wingett, D. Preferential killing of cancer cells and activated human $\mathrm{T}$ cells using ZnO nanoparticles. Nanotechnology 2008, 19, 295103. [CrossRef]

206. Hanley, C.; Thurber, A.; Hanna, C.; Punnoose, A.; Zhang, J.; Wingett, D.G. The influences of cell type and ZnO nanoparticle size on immune cell cytotoxicity and cytokine induction. Nanoscale Res. Lett. 2009, 4, 1409-1420. [CrossRef]

207. Kulkarni, B.D.; Sultana, S.; Bora, M.; Dutta, I.; Paarakh, P.M.; Basappa, V.A. In vitro Cytotoxicity Studies of Zn (Zinc) Nanoparticles Synthesized from Abutilon indicum L. against Human Cervical Cancer (HeLa) Cell Lines. Pharmacogn. J. 2016, 8, 127-131. [CrossRef]

208. Wahab, R.; Kaushik, N.K.; Verma, A.K.; Mishra, A.; Hwang, I.; Yang, Y.-B.; Shin, H.-S.; Kim, Y.-S. Fabrication and growth mechanism of $\mathrm{ZnO}$ nanostructures and their cytotoxic effect on human brain tumor U87, cervical cancer HeLa, and normal HEK cells. JBIC J. Biol. Inorg. Chem. 2011, 16, 431-442. [CrossRef]

209. Dou, J.; He, X.; Liu, Y.; Huang, Z.; Yang, C.; Shi, F.; Chen, D.; Gu, N. Targeted therapeutic effect of anti-ABCG2 antibody combined with nano silver and vincristine on mouse myeloma cancer stem cells. J. Nanoparticle Res. 2013, 15, 2127. [CrossRef]

210. Borrello, I. Can we change the disease biology of multiple myeloma? Leuk. Res. 2012, 36, S3-S12. [CrossRef]

211. Thirukkumaran, C.M.; Shi, Z.Q.; Luider, J.; Kopciuk, K.; Gao, H.; Bahlis, N.; Neri, P.; Pho, M.; Stewart, D.; Mansoor, A. Reovirus as a viable therapeutic option for the treatment of multiple myeloma. Clin. Cancer Res. 2012, 18, 4962-4972. [CrossRef] [PubMed]

212. Abe, M.; Harada, T.; Matsumoto, T. Concise review: Defining and targeting myeloma stem cell-like cells. Stem Cells 2014, 32, 1067-1073. [CrossRef] [PubMed]

213. Li, Z.; Guo, D.; Yin, X.; Ding, S.; Shen, M.; Zhang, R.; Wang, Y.; Xu, R. Zinc oxide nanoparticles induce human multiple myeloma cell death via reactive oxygen species and Cyt-C/Apaf-1/Caspase-9/Caspase-3 signaling pathway in vitro. Biomed. Pharmacother. 2020, 122, 109712. [CrossRef]

214. Laval, J.-M.; Mazeran, P.-E.; Thomas, D. Nanobiotechnology and its role in the development of new analytical devices Presented at SAC 99, Dublin, Ireland, July 25-30, 1999. Analyst 2000, 125, 29-33. [CrossRef]

215. Wahab, R.; Khan, F.; bing Yang, Y.; Hwang, I.; Shin, H.-S.; Ahmad, J.; Dwivedi, S.; Khan, S.T.; Siddiqui, M.A.; Saquib, Q. Zinc oxide quantum dots: Multifunctional candidates for arresting $\mathrm{C} 2 \mathrm{C} 12$ cancer cells and their role towards caspase 3 and 7 genes. Rsc Adv. 2016, 6, 26111-26120. [CrossRef]

216. Wang, J.; Gao, S.; Wang, S.; Xu, Z.; Wei, L. Zinc oxide nanoparticles induce toxicity in CAL 27 oral cancer cell lines by activating PINK1/Parkin-mediated mitophagy. Int. J. Nanomed. 2018, 13, 3441. [CrossRef]

217. Bar, H.; Bhui, D.K.; Sahoo, G.P.; Sarkar, P.; Pyne, S.; Misra, A. Green synthesis of silver nanoparticles using seed extract of Jatropha curcas. Colloids Surf. A Physicochem. Eng. Asp. 2009, 348, 212-216. [CrossRef]

218. Bi, C.; Li, J.; Peng, L.; Zhang, J. Biofabrication of Zinc oxide nanoparticles and their in-vitro cytotoxicity towards gastric cancer (MGC803) cell. Biomed. Res. 2017, 28, 2065-2069.

219. Perera, W.; Dissanayake, R.K.; Ranatunga, U.; Hettiarachchi, N.; Perera, K.; Unagolla, J.M.; De Silva, R.; Pahalagedara, L. Curcumin loaded zinc oxide nanoparticles for activity-enhanced antibacterial and anticancer applications. RSC Adv. 2020, 10, 30785-30795. [CrossRef]

220. Padmanabhan, A.; Kaushik, M.; Niranjan, R.; Richards, J.S.; Ebright, B.; Venkatasubbu, G.D. Zinc oxide nanoparticles induce oxidative and proteotoxic stress in ovarian cancer cells and trigger apoptosis independent of p53-mutation status. Appl. Surf. Sci. 2019, 487, 807-818. [CrossRef]

221. Bai, D.-P.; Zhang, X.-F.; Zhang, G.-L.; Huang, Y.-F.; Gurunathan, S. Zinc oxide nanoparticles induce apoptosis and autophagy in human ovarian cancer cells. Int. J. Nanomed. 2017, 12, 6521. [CrossRef] [PubMed]

222. Sun, W.; Bao, J.; Lin, W.; Gao, H.; Zhao, W.; Zhang, Q.; Leung, C.-H.; Ma, D.-L.; Lu, J.; Chen, X. 2-Methoxy-6-acetyl-7-methyljuglone (MAM), a natural naphthoquinone, induces NO-dependent apoptosis and necroptosis by $\mathrm{H} 2 \mathrm{O} 2$-dependent JNK activation in cancer cells. Free Radic. Biol. Med. 2016, 92, 61-77. [CrossRef]

223. Yu, C.-I.; Chen, C.-Y.; Liu, W.; Chang, P.-C.; Huang, C.-W.; Han, K.-F.; Lin, I.-P.; Lin, M.-Y.; Lee, C.-H. Sandensolide induces oxidative stress-mediated apoptosis in oral cancer cells and in zebrafish xenograft model. Mar. Drugs 2018, 16, 387. [CrossRef] [PubMed]

224. Cho, H.-D.; Lee, J.-H.; Moon, K.-D.; Park, K.-H.; Lee, M.-K.; Seo, K.-I. Auriculasin-induced ROS causes prostate cancer cell death via induction of apoptosis. Food Chem. Toxicol. 2018, 111, 660-669. [CrossRef] [PubMed]

225. Wang, S.-W.; Lee, C.-H.; Lin, M.-S.; Chi, C.-W.; Chen, Y.-J.; Wang, G.-S.; Liao, K.-W.; Chiu, L.-P.; Wu, S.-H.; Huang, D.-M. ZnO nanoparticles induced caspase-dependent apoptosis in gingival squamous cell carcinoma through mitochondrial dysfunction and p70S6K signaling pathway. Int. J. Mol. Sci. 2020, 21, 1612. [CrossRef] [PubMed] 
226. Goorabjavari, S.V.M.; Golmohamadi, F.; Haririmonfared, S.; Ahmadi, H.; Golisani, S.; Yari, H.; Hasan, A.; Edis, Z.; Ale-Ebrahim, M.; Sharifi, M. Thermodynamic and anticancer properties of inorganic zinc oxide nanoparticles synthesized through co-precipitation method. J. Mol. Liq. 2021, 330, 115602. [CrossRef]

227. Namvar, F.; Rahman, H.S.; Mohamad, R.; Azizi, S.; Tahir, P.M.; Chartrand, M.S.; Yeap, S.K. Cytotoxic effects of biosynthesized zinc oxide nanoparticles on murine cell lines. Evid. Based Complement. Altern. Med. 2015, 2015. [CrossRef]

228. Yuan, L.; Wang, Y.; Wang, J.; Xiao, H.; Liu, X. Additive effect of zinc oxide nanoparticles and isoorientin on apoptosis in human hepatoma cell line. Toxicol. Lett. 2014, 225, 294-304. [CrossRef]

229. Stowe, D.F.; Camara, A.K. Mitochondrial reactive oxygen species production in excitable cells: Modulators of mitochondrial and cell function. Antioxid. Redox Signal. 2009, 11, 1373-1414. [CrossRef] [PubMed]

230. Moghimipour, E.; Rezaei, M.; Ramezani, Z.; Kouchak, M.; Amini, M.; Angali, K.A.; Dorkoosh, F.A.; Handali, S. Transferrin targeted liposomal 5-fluorouracil induced apoptosis via mitochondria signaling pathway in cancer cells. Life Sci. 2018, 194, 104-110. [CrossRef] [PubMed]

231. Guo, C.; Sun, L.; Chen, X.; Zhang, D. Oxidative stress, mitochondrial damage and neurodegenerative diseases. Neural Regen. Res. 2013, 8, 2003.

232. Jiang, J.; Pi, J.; Cai, J. The advancing of zinc oxide nanoparticles for biomedical applications. Bioinorg. Chem. Appl. 2018, 2018, 1062562. [CrossRef] [PubMed] 